\title{
Integration of DNA-Based Approaches in Aquatic Ecological Assessment Using Benthic Macroinvertebrates
}

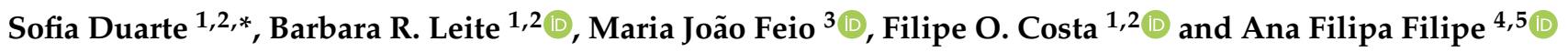 \\ 1 Centre of Molecular and Environmental Biology (CBMA), Department of Biology, University of Minho, \\ Campus de Gualtar, 4710-057 Braga, Portugal; barbaral@bio.uminho.pt (B.R.L.); \\ fcosta@bio.uminho.pt (F.O.C.) \\ 2 Institute of Science and Innovation for Bio-Sustainability (IB-S), University of Minho, Campus de Gualtar, \\ 4710-057 Braga, Portugal \\ 3 Department of Life Sciences, MARE-Marine and Environmental Sciences Centre, University of Coimbra, \\ 3000-456 Coimbra, Portugal; mj@@ci.uc.pt \\ 4 School of Agriculture, University of Lisbon, Tapada da Ajuda, 1349-017 Lisboa, Portugal; affilipe@gmail.com \\ 5 CIBIO/InBIO—Research Centre in Biodiversity and Genetic Resources, University of Porto, \\ Campus de Vairão, 4485-661 Vairão, Portugal \\ * Correspondence: sduarte@bio.uminho.pt
}

check for updates

Citation: Duarte, S.; Leite, B.R.; Feio, M.J.; Costa, F.O.; Filipe, A.F. Integration of DNA-Based Approaches in Aquatic Ecological Assessment Using Benthic Macroinvertebrates. Water 2021, 13, 331. https://doi.org/10.3390/ w13030331

Academic Editor: Jan H. Janse Received: 21 December 2020

Accepted: 25 January 2021

Published: 29 January 2021

Publisher's Note: MDPI stays neutral with regard to jurisdictional claims in published maps and institutional affiliations.

Copyright: (c) 2021 by the authors. Licensee MDPI, Basel, Switzerland. This article is an open access article distributed under the terms and conditions of the Creative Commons Attribution (CC BY) license (https:// creativecommons.org/licenses/by/ $4.0 /)$.

\begin{abstract}
Benthic macroinvertebrates are among the most used biological quality elements for assessing the condition of all types of aquatic ecosystems worldwide (i.e., fresh water, transitional, and marine). Current morphology-based assessments have several limitations that may be circumvented by using DNA-based approaches. Here, we present a comprehensive review of 90 publications on the use of DNA metabarcoding of benthic macroinvertebrates in aquatic ecosystems bioassessments. Metabarcoding of bulk macrozoobenthos has been preferentially used in fresh waters, whereas in marine waters, environmental DNA (eDNA) from sediment and bulk communities from deployed artificial structures has been favored. DNA extraction has been done predominantly through commercial kits, and cytochrome c oxidase subunit I (COI) has been, by far, the most used marker, occasionally combined with others, namely, the $18 \mathrm{~S}$ rRNA gene. Current limitations include the lack of standardized protocols and broad-coverage primers, the incompleteness of reference libraries, and the inability to reliably extrapolate abundance data. In addition, morphology versus DNA benchmarking of ecological status and biotic indexes are required to allow general worldwide implementation and higher end-user confidence. The increased sensitivity, high throughput, and faster execution of DNA metabarcoding can provide much higher spatial and temporal data resolution on aquatic ecological status, thereby being more responsive to immediate management needs.
\end{abstract}

Keywords: aquatic ecosystems; biomonitoring; bioassessment; benthic macroinvertebrates; DNA metabarcoding

\section{Introduction}

One of the major challenges we face today is to protect and restore aquatic ecosystems, their ecological quality, and other services while preserving biodiversity. Efforts across the globe have been focused on adopting regulations to protect aquatic ecosystems and achieve a "good status," meaning quality is only slightly altered by human influence. For example, large-scale nation-wide monitoring has been established in the USA and Canada through the EPA National Aquatic Resource Surveys (NARS) and the Canadian Aquatic Biomonitoring Network, respectively [1]. In Europe, homologous regulations include the Water Framework Directive (WFD, Directive 2000/60/EC) and the Marine Strategy Framework Directive (MSFD, Directive 2008/56/EC), which have been addressing aquatic environmental degradation for more than 10 years and have implemented a European-wide ecological assessment of water bodies [2-5]. 
One of the major challenges to achieving the "good status" of water bodies is to assess the impacts of human activities rapidly and efficiently, or the effects of restoration measures. The resulting list of taxa and their abundances are used to calculate biotic indices or metrics measuring the ecological quality status. A large number of aquatic biotic indices has been developed to assess the ecological quality based on morphological identification of indicator organisms [6,7]. One of the most commonly used biological quality elements (BQEs) is benthic macroinvertebrate fauna due to the predictable response to human disturbances in a broad range of aquatic ecosystems, from rivers, streams, and lakes to estuaries and marine ecosystems, allowing the monitoring of long-term responses and site-specific impacts $[2,8,9]$. In addition, benthic invertebrates are extremely important by providing invaluable functions and services in aquatic ecosystems (i.e., food, water filtration, and organic matter decomposition) [10].

Routine biodiversity assessments of macrobenthic communities have been carried-out exclusively through traditional morphology-based species identification, providing both taxa occurrence and abundance data $[9,11-13]$. This is a low-throughput, time-consuming, and costly approach that requires considerable taxonomic expertise [14], which also results in low throughput of biomonitoring samples. Assignments to species are often challenging because of the inherent difficulty of the identification process, the absence of key body parts for diagnosis, or occurrence in developmental stages not amenable to rigorous morphological identification (e.g., larval stages and small juveniles) [15]. Morphology-based species identifications can be particularly challenging for marine communities due to their high phylogenetic diversity of species combined with the obstacles of sampling in these complex ecosystems, which may prevent the full taxonomic identification of a bulk sample [16,17]. The inability to improve species assessment, in time and discrimination, combined with incomplete taxonomic keys, also hinders an effective assessment of the status and changes in macroinvertebrate communities. Moreover, biomonitoring is conducted most of the time in only one or two events per six-year management cycle due to the high cost and time spent in sampling and identification together [12]. In addition, despite the importance of monitoring and assessment, the current economic crisis is leading some countries to reduce the budgets dedicated to monitoring [18].

Modern technologies, namely, DNA-based identification tools, have great potential to improve monitoring approaches [19-21] and offer an efficient complement to morphological-based identifications $[15,22,23]$. DNA-based methodologies have been proposed to assess the ecological status by detection of specific species or full community diversity, enabling higher throughput and efficiency in bioassessment of macroinvertebrates communities [18,24-27]. In particular, DNA barcoding (i.e., the use of short sequencesthe DNA barcodes-for species identification) [28,29], coupled with high-throughput sequencing, makes (e)DNA metabarcoding the tool of choice of the 21st century to be used in biomonitoring $[18,21,24,29-31]$. To identify multiple species rapidly and accurately, DNA can be extracted from a bulk sample (i.e., DNA metabarcoding), or directly extracted from environmental samples (e.g., sediment and water), which is defined as environmental DNA (eDNA) metabarcoding [32,33]. Both strategies differ in DNA source and applications; in contrast to DNA metabarcoding, which is used in relatively easy-to-isolate communities, eDNA is more applicable to target communities hard to isolate from an environmental matrix (e.g., meiofauna [34]).

Several studies have already implemented (e)DNA metabarcoding approaches to assess macroinvertebrates diversity in a wide range of aquatic ecosystems, from rivers (e.g., [24,35-37]) to transitional waters (e.g., [15,27,38,39]) and coastal areas (e.g., [22,40-43]), possibly enabling comparisons among studies and across a large temporal, spatial, and geographical scale. However, the standardization of the adopted methodologies is very difficult because a variety of factors can largely differ across studies-sampling (target community, season, effort, type of sampling devices, and site) and processing methodologies, including preservation methods and DNA extraction, PCR amplification (marker loci and primer pairs) and sequencing (platforms used) [44,45], in addition to the bioinformatics 
pipelines [46]. Some of these differences in the metabarcoding workflow were already highlighted as drawbacks [20,32,44,45,47], which complicate the implementation of a standard protocol for regular biomonitoring using (e)DNA metabarcoding approaches [20]. The accuracy of DNA-based assessments is also affected by the lack of representative sequences for many species and the low quality of records and taxonomic incongruences present in reference databases [48-51].

Since the first studies were published about 10 years ago, the number of publications using (e)DNA metabarcoding to diagnose aquatic macroinvertebrate species has been growing steadily. Here, we comprehensively review this already sizeable body of literature, aiming to gauge the general status of progress on the application of (e)DNA metabarcoding to freshwater and marine macroinvertebrates, with a focus on assessing the methodological diversity of protocols used-from field sampling to laboratory molecular analyses. We highlight major limitations and the challenges ahead for scaling up the assessments and enable their implementation in biomonitoring programs of aquatic environments across the world. Finally, we provide a set of recommendations for improvement based on the reviewed literature.

\section{Materials and Methods}

We conducted a literature search by querying the Web of Science for articles in which DNA metabarcoding was used for the bioassessment of macroinvertebrate taxa in aquatic ecosystems (fresh water, transitional, and marine), on 12 November 2020. We searched by topic, which included the words in the title, abstract, and keywords. The combinations of terms that were used to find articles involving bioassessment, DNA metabarcoding, benthic macroinvertebrate taxa, and aquatic ecosystems, are detailed in Table 1.

Table 1. Combinations of terms used to search the Web of Science for articles involving bioassessment, DNA metabarcoding, benthic macroinvertebrate taxa, and aquatic ecosystems. The presence of the * in some search terms means that any words containing them after or before should be displayed in the search (e.g., *monitoring, should also display biomonitoring).

\begin{tabular}{cccc}
\hline First Term & Second Term & Third Term & Fourth Term \\
\hline & metabarcoding OR & & aquatic OR \\
high throughput & & \\
& sequencing OR & & freshwater* OR fresh \\
& high-throughput & & water* OR river* OR \\
& sequencing OR HTS & invertebrate* OR $^{*}$ & stream* OR lake* OR \\
*monitoring OR & OR next generation & macroinvertebrate* & dam* OR reservoir* \\
*assessment & sequencing OR & OR benth* & OR estuar* OR \\
& next-generation & & transition* OR marine \\
& sequencing OR NGS & & OR lagoon* OR sea* \\
& OR eDNA OR & & OR coast* \\
& environmental DNA & & \\
\hline
\end{tabular}

The information retrieved from each selected publication, when available, included (Supplementary Materials: Table S2) (1) the geographic area, (2) the environment (i.e., fresh, transitional, or marine waters), (3) the sampling strategy (e.g., no. of sites/locations, substrates-benthic substrates, water or sediment, targets type-eDNA/eRNA, or bulk communities), (4) sample processing and preservation, (5) the DNA extraction protocols, (6) the targeted marker loci and primer pairs used, (7) the experimental controls used, and (8) the sequencing platforms employed. We opted to focus on the procedures used through the analytical chain of the DNA metabarcoding approach before sequences processing, which are those that may have the strongest influence on the final output and can be more variable among different labs. In addition, as long as (1) adequate data quality filters are applied to the data, (2) appropriate Operational Taxonomic Units (OTU) clustering algorithms are employed, and (3) the species assignments of OTUs are conducted preferentially against curated databases, the results should be reliable and replicable [52]. Furthermore, 
in the case of macroinvertebrate metabarcoding, the desired rank of identification is at the species level, and, thus, the OTU clustering cut-off value will not have much impact on the results. Moreover, with the growing trend to use exact sequence variants (ESV) for taxonomic assignment, the OTU-clustering steps can be bypassed [53].

Our initial literature search yielded 257 papers. Records from the search results were screened and selected for the analysis if the study targeted benthic macroinvertebrate taxa and used an (e)DNA metabarcoding approach. We found 83 papers meeting these criteria, to which seven more papers were added that met our target and were somehow missed by the search terms used [41,43,54-58] (Supplementary Materials: Table S1). Papers that were not primary research articles (e.g., reviews), or targeted particular invertebrate species were excluded from the analysis.

The results were illustrated through point-and-bar graphs using GraphPad Prism 9.0, (San Diego, CA, USA) with an indication of the number of studies where a particular approach was used for a particular aquatic ecosystem (fresh water, transitional, or marine). In most figures, results of transitional and marine waters were joined together because the approaches are broadly identical for both types of ecosystems. A map was built using the information available about the location of sampling sites in the respective papers and employing ArcMap 10.5 (ESRI, Redlands, CA, USA). The relative frequencies of methods used during the several stages of the DNA metabarcoding workflow that are analyzed in the current review (i.e., environment, target, preservation, DNA extraction method, marker loci, and sequencing platform) were represented in a diagram constructed in SankeyMATIC (http://sankeymatic.com/build/). In the diagram, the thickness of the lines corresponds to the number of publications using each methodology.

\section{Results and Discussion}

\subsection{Progress of Metabarcoding Studies in Aquatic Bioassessment Using Benthic Macroinvertebrates}

Since the earliest study published in 2010 [58], there has been a steep growth during the following years in the number of papers published on the theme, with most studies published between 2016 and 2020 (Figure 1). An overview of the studies indicates that metabarcoding-targeting benthic macroinvertebrates have been widely used in ecological assessments in aquatic ecosystems, for example, to assess (1) the effects of contaminants in urbanized, industrialized, and agricultural stream and estuarine areas (e.g., [15,27,39,58-65]), (2) the effects of stream fragmentation due to dams [66], (3) longterm effects of pesticides [67], oil spills [68], or offshore oil and gas drilling activities [40,69,70], or (4) the effects of invasive species (e.g., invasive algae [71] and crucian carp [72]). It has also proven to be a reliable tool to characterize archive collections of specimens [73], to estimate intraspecific genetic diversity [74], to early detect and monitor invasive species [42,75-77], to be used in the biomonitoring of sea-based fish farms [78,79], and to identify large biogeographic patterns $[80,81]$ and new molecular and cryptic metazoan diversity, in particular in marine ecosystems [55,81-84].

The majority of the studies have been conducted on fresh waters (52\%), followed by fully marine waters $(42 \%)$, while in estuaries or transitional waters, benthic macrofauna have been much less assessed using (e)DNA metabarcoding approaches (ca. 8\%) (Figure 1). 


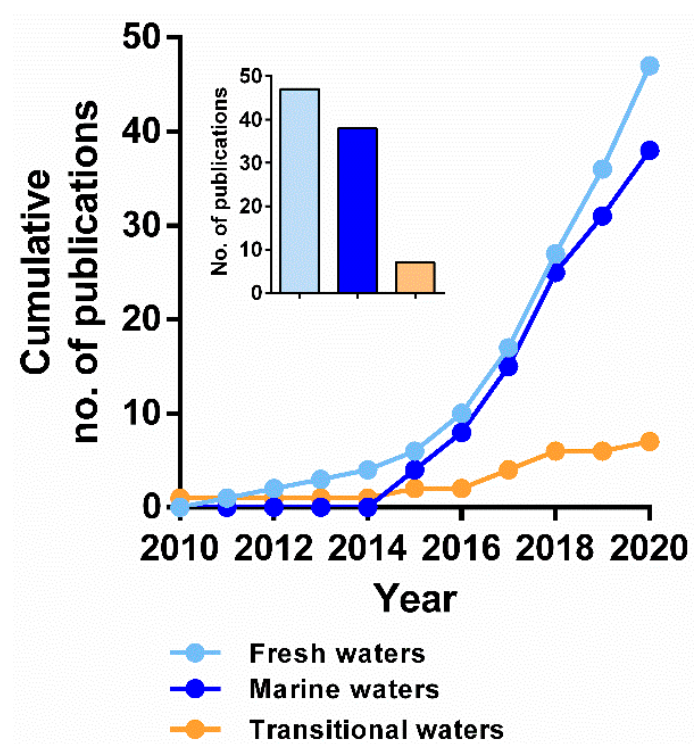

Figure 1. The cumulative number of articles published over the last decade meeting the criteria that assessed benthic macroinvertebrate taxa using (e)DNA metabarcoding on each type of aquatic ecosystems.

\subsection{Methodological Assessment \\ 3.2.1. Sampling Strategies}

Sampling strategies were highly variable, in particular in marine waters (Table S2). Regarding the number of geographical regions surveyed, most studies conducted in fresh waters targeted one single region (e.g., $[23,59,85,86])$, while in marine waters, a few studies have targeted multiple seas or oceans, therefore covering a large geographical extent $[80-82,87]$ (Table S2). The location of the sampled regions has been mostly concentrated in the Palearctic, Nearctic (Northern Hemisphere), and Australasia, with a few studies in the Antarctic and IndoMalay (Southern Hemisphere) and absent in Neotropics and Afrotropics (Figure 2). In fresh waters, most studies pertained to the macroinvertebrate fauna of watercourses (rivers or streams, e.g., $[23,85,86,88]$ ), and a smaller amount in ponds (e.g., [60,72,89]), wetlands (e.g., [54,90,91]), lakes (e.g., [61,92]), or reservoirs (e.g., [57]), whereas in marine waters, most studies were conducted in open coastal regions (e.g., [80,93-96]), with a few in the deep sea [87,97]. In transitional waters, studies have been performed in estuaries (e.g., [15,27,39,58]) and also in coastal lagoons [98].

In fresh waters, studies vary from a single (e.g., [99]) to multiple sites, i.e., locations (e.g., $[61,63,67,74,85,100])$, and within each site, some studies consider multiple sampling points so that all habitats or different sampling times were represented in the sample, and the possibility of detecting the occurring macroinvertebrate fauna increases (e.g., $[36,59,62,101]$ ) (Table S2). In most cases, sampling points from the same site are pooled and processed as a single sample following customary procedures (e.g., [23,37,102-104]). In marine waters, within each sampled region, the number of sampling sites also varied from single (e.g., [40,41,98,105]) to multiple (e.g., $[27,55,81,83])$, but within each site, most surveys included multiple sites. A lower number of studies addressed temporal or seasonal effects $[63,75,95]$ (Table S2). 


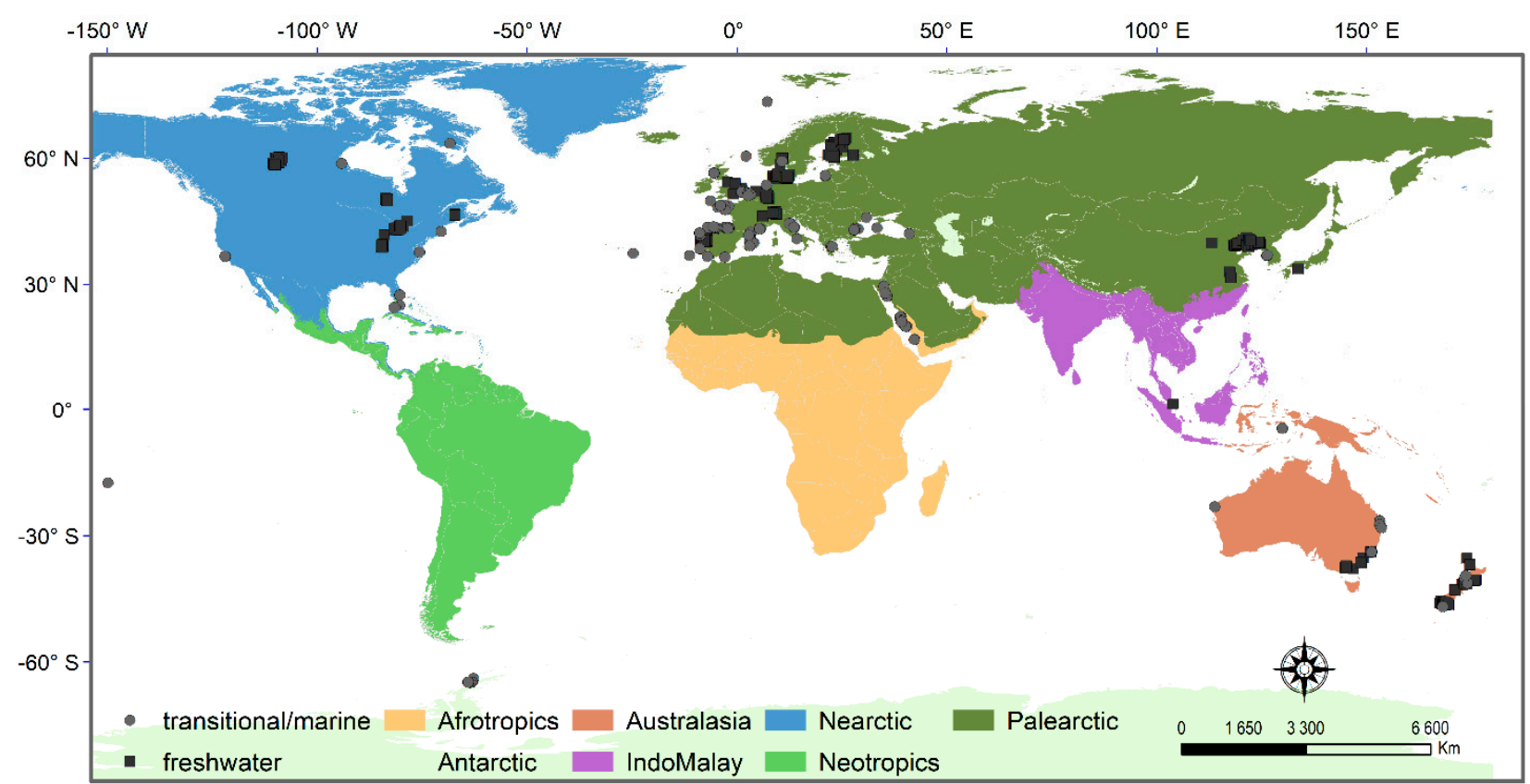

Figure 2. Map showing the distribution of the studies reviewed here; each site is represented by a dot, with colors indicating the biogeographical region.

In fresh waters, most surveys collected bulk organismal samples from benthic substrates ( $>80 \%$ of the publications from fresh waters), by using kick-net or Surber samplers and by following customary procedures to sort macroinvertebrate specimens from any substrate or debris (e.g., $[23,31,67,85,86,88,106-108]$ ) (Table S2). One study used an electroshocking method as an alternative to kick netting [109]. On the other hand, in transitional and marine waters, the most sampled substrate was sediment to harvest either environmental DNA (eDNA) (ca. 43\%) or bulk benthic communities (ca. 11\%) (Figure 3), collected with sediment cores (e.g., [15,38,82,94,97]) or grabs (e.g., van Veen grab, [39,43,69,78,79,95,110]) (Table S2). Sediment sieving has been often employed to separate bulk organisms from the environmental matrix (i.e., $0.5 \mathrm{~mm}$ to $2 \mathrm{~mm}$ mesh size, e.g., [15,22,66,107]), and slicing into layers is often used to subsample marine sediments from different depths $[39,87,97]$ (Table S2). Bulk organisms sieving in different size fractions (e.g., marine: $>106 \mu \mathrm{m}$ to $>2 \mathrm{~mm},[41,55,81,93,111]$ ), sorting into different size categories (fresh waters, $2.5 \mathrm{~mm}$ to $>10 \mathrm{~mm}$ ) [72,112], or detecting by the naked eye [86,109], has been performed to improve the detection of smaller sized organisms before DNA extraction, but at an extra cost of an increase in sample processing time. A feasible option may be sorting samples into basic taxonomic groups that require little taxonomic knowledge (e.g., Annelida, Arthropoda, Mollusca) and less time effort, and that can greatly improve the recovery of taxa through DNA metabarcoding [113]. 


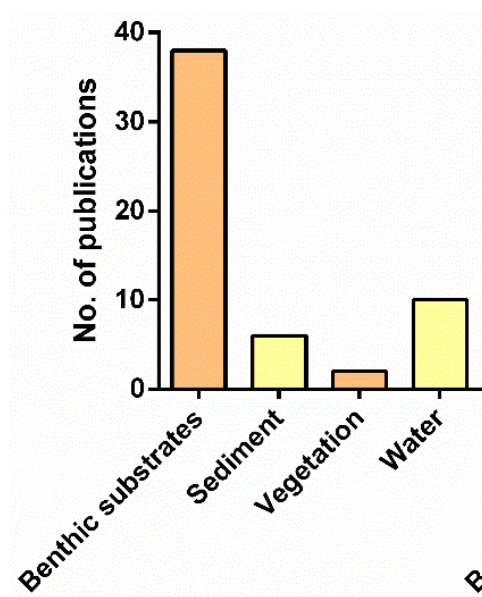

(a)

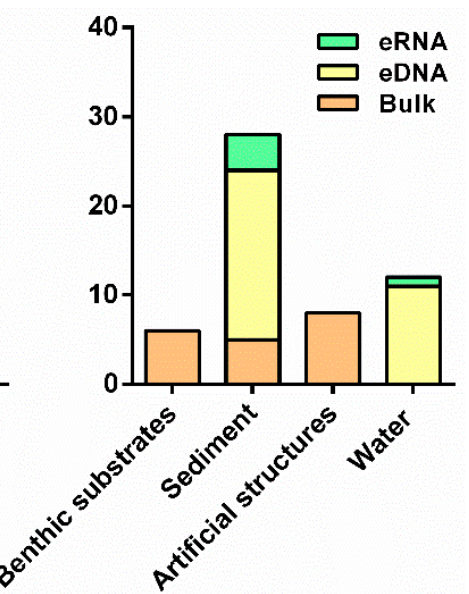

(b)

Figure 3. Sampled substrates and targets type (environmental RNA (eRNA), environmental DNA (eDNA), or bulk community) for assessing macroinvertebrate diversity through metabarcoding in (a) fresh and (b) transitional/marine waters.

In marine waters, benthic substrates, particularly hard-bottom ones, have been also fairly investigated through DNA metabarcoding (Figure 3). These communities have been mainly sampled through deployment of artificial substrates (ca. 18\%, e.g., [41,80,81,93,114]) or by taking samples directly from scraped surfaces of standardized area (ca. $14 \%$, $[71,84,96,115,116])$. Among the artificial substrate methods, the autonomous reef monitoring structures (ARMS) have been the most widely used (in seven studies; $[41,55,81,93,98,111,114]$ ), while artificial substrate units (ASUs) have been less used (only in one study found in our literature search [80]) (Figure 3, Table S2). In particular, the joint use of ARMS with metabarcoding approaches provides a standard method to survey the marine cryptobiome, which encompasses phylogenetically and ecologically diverse groups inhabiting benthic ecosystems and very difficult to assess by using traditional approaches [81]. The use of ARMS sampling may become considerably widespread during the next years [117], which would be crucial to generate comparable biodiversity assessments across large spatial and temporal scales and improve biomonitoring of marine benthic ecosystems, resulting in relevant information to managers and stakeholders [55,81]. However, substrates with more complex structures, such as ramifications resembling macroalgae, appear to provide refuge for particular taxa that may not occur in ARMS [118].

In contrast to metabarcoding, which has been mostly applied to bulk DNA of benthic macroinvertebrates, a fair proportion of the studies targeted water eDNA (marine; ca. $25 \%$, e.g., $[42,56,76,77,82,83,96]$ and fresh; ca. $21 \%$, e.g., $[57,64,65,90,92,119]$ ) (Figure 3). The eDNA, which is extracted directly from environmental matrices, such as water and sediment, tend to be made up of a mix of intra-organismal DNA (e.g., from small organisms) and extra-organismal DNA or trace eDNA shed from large organisms (e.g., body parts, secreted mucus, and feces, tissues, and cells) [30,33,34]. In particular, in the marine realm, sampling water involves much less effort and is more cost-effective than sampling bulk samples (e.g., avoiding sampling through diving) [56,96]. In these studies, most samples were collected just below the water surface, both in marine and in fresh waters (e.g., $[42,76,83,103,119])$. However, in marine ecosystems, a few studies considered multiple layers in order to take into account the water column stratification and vertical community structuring $[75,120,121]$. Moreover, in marine environments, higher volumes (e.g., $5 \mathrm{~L}$ in Cowart et al. [83] and Zhang et al. [120] and 20 L in López-Escardó et al. [82]) are sometimes needed due to the magnitude of water masses and greater dilution of eDNA. For instance, López-Escardó et al. [82] pre-filtered a big volume of water (i.e., $20 \mathrm{~L}$ ) through a larger pore size membrane to avoid filter clogging. By contrast, a lower amount of water is commonly filtered in fresh waters (e.g., $250 \mathrm{~mL}$ in Carraro et al. [103], $1.5 \mathrm{~L}$ in Gleason et al. [119], 
2 L in Bagley et al. [64], and $4 \mathrm{~L}$ in Fernandez et al. [122]; see Table S2 for more details), and only one depth considered, usually below the surface. However, even in the close vicinity of the benthic layer, water eDNA has been found to reflect poorly the nearby benthic taxa in both marine (e.g., [77,96]) and fresh waters (e.g., [90,102,119]). For instance, in fresh waters, bulk-sample metabarcoding resembled much better morphology-based biomonitoring outcomes $[90,102]$ because indicator macroinvertebrate taxa were captured (i.e., EPTO-Ephemeroptera, Plecoptera, Trichoptera and Odonata). On the other hand, water eDNA may detect better the impact of stressors because it also incorporates nonmetazoan taxa [102]. Even so, eDNA studies have a great potential for detecting differences in community compositions at relatively large scales [103], and its use can be very advantageous for (1) providing a rapid snapshot of local species compositions [75], (2) detecting non-indigenous species $[42,57,75,76]$ early, (3) inferring the impact of stressors in stream ecosystems at larger scales $[64,102]$, and (4) providing a rapid assessment protocol to supplement more intensive field sampling efforts [64]. However, when smaller-scale spatial resolution is required, bulk tissue metabarcoding provides a more accurate representation of local stream macroinvertebrate communities [119].

Even though the potential of using eDNA for detecting small organisms (e.g., planktonic micro-eukaryotes and meiofauna) or large organisms (e.g., fish) in small sediment samples can be effective (e.g., $[39,78,123])$, its broad use for biodiversity assessment and monitoring purposes of benthic macroinvertebrates should be employed with caution (e.g., $[94,110])$. For instance, in comparative studies, only a small proportion of the taxa identified through morphological methods was retrieved by extracting eDNA directly from estuarine benthic sediments [110]. In addition, the direct extraction of eDNA from Wadden sea sediments, without prior cell lysis, yielded the lowest taxa diversity, and thus an incomplete view of benthic biodiversity [94]. However, interestingly, Steyaert et al. [38] found a reduction in species richness in sieved sediment samples through metabarcoding when compared to non-sieved samples, suggesting that the direct use of sediments may take into account both eDNA (originated from macroinvertebrates) and organisms lower than $500 \mu \mathrm{m}$, mostly meiofauna.

Environmental RNA (eRNA) has been less frequently used and only employed in marine waters in the scope of the searched articles, in particular in sediments (ca. $11 \%)[69,78,79,82,87,105]$. Environmental DNA, trimmed by shared OTUs with eRNA, has been found to represent a better proxy for assessing anthropogenic impacts on marine benthic ecosystems $[69,105]$. However, using eRNA requires specific storage conditions of samples and workflow protocols, which are more expensive and time-consuming, and therefore much less adopted than eDNA, which allows to conduct more logistically realistic, repeatable, and reliable surveys [87].

\subsubsection{Sample Preservation, Pre-Processing, and DNA Extraction Protocols}

Concerning sample preservation, most studies have been preserving benthic macroinvertebrates in ethanol $95-96 \%$ at $4-5{ }^{\circ} \mathrm{C}$ (e.g., [31,102,110,115]) or $-20^{\circ} \mathrm{C}$ (e.g., $[15,35,71$, $84,90,96,114,116,124]$ ) until DNA extraction (Table S2). In fresh waters, Nichols et al. [107] found that storing the samples at room temperature or after heating (i.e., $50{ }^{\circ} \mathrm{C}$ for $3 \mathrm{~h}$ ) had no effect on macroinvertebrate taxa detection in comparison with preserving at lower temperatures $\left(-20^{\circ} \mathrm{C}\right)$. Other methods, in particular for sessile fauna retrieved from ARMS in marine waters, include the preservation of homogenized sub-samples in dimethyl sulfoxide (DMSO) buffer at $-20^{\circ} \mathrm{C}$ (Table S2) (e.g., [41,55,81,93]), resulting in samples with less degraded and higher quality DNA than those preserved in ethanol [41]. The influence of preservation time has been less studied, but Nichols et al. [107] found no effect on freshwater macroinvertebrate taxa detection for samples stored from up to one year in $95 \%$ ethanol and at room temperature.

Homogenization of bulk samples with a kitchen blender (e.g., [71,84,88,96,106,114]), an ultra-turrax homogenizer (e.g., [63,112,113]), a fast-prep equipment with MP lysing matrix tubes (MP Biomedicals, Irvine, CA, USA) [24,54], or a mortar and pestle (e.g., [27,65,125]) 
has been widely employed before DNA extraction, in addition to sediment homogenization (e.g., $[38,62,87,110]$ ) (Table S2). These procedures ensure sample homogeneity, which may increase the recovered diversity, in particular of rare or low abundance taxa. Most studies remove the preservation solutions and ethanol before DNA extraction, and samples are often dried to get rid out of any ethanol traces, which may interfere with subsequent steps in the workflow (e.g., $[23,52,66,67,89,125])$. Grounding dried bulk samples collected in fresh waters by using, for example, bead mills, allows DNA extractions of the entire community using a small quantity of tissue powder (e.g., up to $15 \mathrm{mg}$ ), which is much more feasible for large-scale studies and to be routinely implemented [35,52,112].

Regarding sediment preservation for eDNA analysis, most samples have been directly frozen (at $-20{ }^{\circ} \mathrm{C}$ or $-80{ }^{\circ} \mathrm{C}$ ) (e.g., $\left.[38,60,61,94,95,110]\right)$, preserved in LifeGuard Soil preservation solution (MoBio, Carlsbad, CA, USA, later acquired by Qiagen, Hilden, Germany) $[69,70,78,105]$, in ethanol at $-20^{\circ} \mathrm{C}[40,43,126]$, or freeze-dried [62] (Table S2). The filters' material used for water eDNA analysis (i.e., glass microfiber, cellulose nitrate, nylon, polycarbonate, or polyethersulfone), and their pore size $(0.2 \mu \mathrm{m}$ to $5 \mu \mathrm{m})$, have been highly variable among studies in both marine and fresh waters (e.g., $[36,64,65,70,75$, $82,96,102,103,127])$ (Table S2). Studies comparing the effects of filter material or the pore size on water eDNA recovery are practically absent, but in marine ecosystems, Deiner et al. [128] found a significant effect of the filter material (glass microfiber versus cellulose nitrate), but not of the pore size $(0.2 \mu \mathrm{m}$ to $1.2 \mu \mathrm{m})$. Although less adopted, the use of a larger pore size (i.e., $5 \mu \mathrm{m}$ ) may be better suited for filtering larger volumes, in particular in turbid sites [119]. Moreover, the filters have been often stored frozen (at $-20^{\circ} \mathrm{C}$ or $-80^{\circ} \mathrm{C}$ ) without applying any preservative solution (e.g., [65,70,82,83,103,119,122,127]) (Table S2). Other less used alternatives include preservation of the filters in ethanol at $4{ }^{\circ} \mathrm{C}$ [102] or $-20{ }^{\circ} \mathrm{C}[64,77]$, or in Longmire's buffer [75] (Table S2).

Most studies, particularly in marine waters, have been using DNA extraction kits for all types of samples (bulk, sediments, and filters), in particular, the DNeasy PowerMax Soil kit (MoBio, Carlsbad, CA, USA, later acquired by Qiagen, Hilden, Germany), which allows the extraction of up to $10 \mathrm{~g}$ of material (ca. $26 \%$, Figure 4, Table S2). This demonstrates the ability for recovering high-quality DNA from a high range of environmental matrices $[70,87,126]$ or bulk samples containing high phylogenetic diversity $[22,27,84,96]$. Hermans et al. [36] compared the efficiency of six commercial kits to extract DNA from different biological targets, including macroinvertebrate taxa, and from different environmental matrices (e.g., water, sediment, and litter) and found the DNeasy PowerSoil (MoBio, Carlsbad, CA, USA, later acquired by Qiagen, Hilden, Germany) the most universally applicable DNA extraction method, yielding high-quality results and with lower bias than other methods. In terms of kit chemistry, both PowerMax and PowerSoil are identical, but PowerMax allows to process a much larger sample amount (10 g versus $0.25 \mathrm{~g}$ ), and thus, the chance to detect small specimens or low biomass specimens greatly increases. The DNeasy Blood \& Tissue kit (Qiagen, Hilden, Germany) has been also widely used (ca. 20\%, Figure 4), in particular in fresh waters. It has been argued that the chemical and enzymatic lysis used by this method is considered to be more suited to the detection of animals because cells are easier to lyse while preventing excessive DNA shearing [36]. 


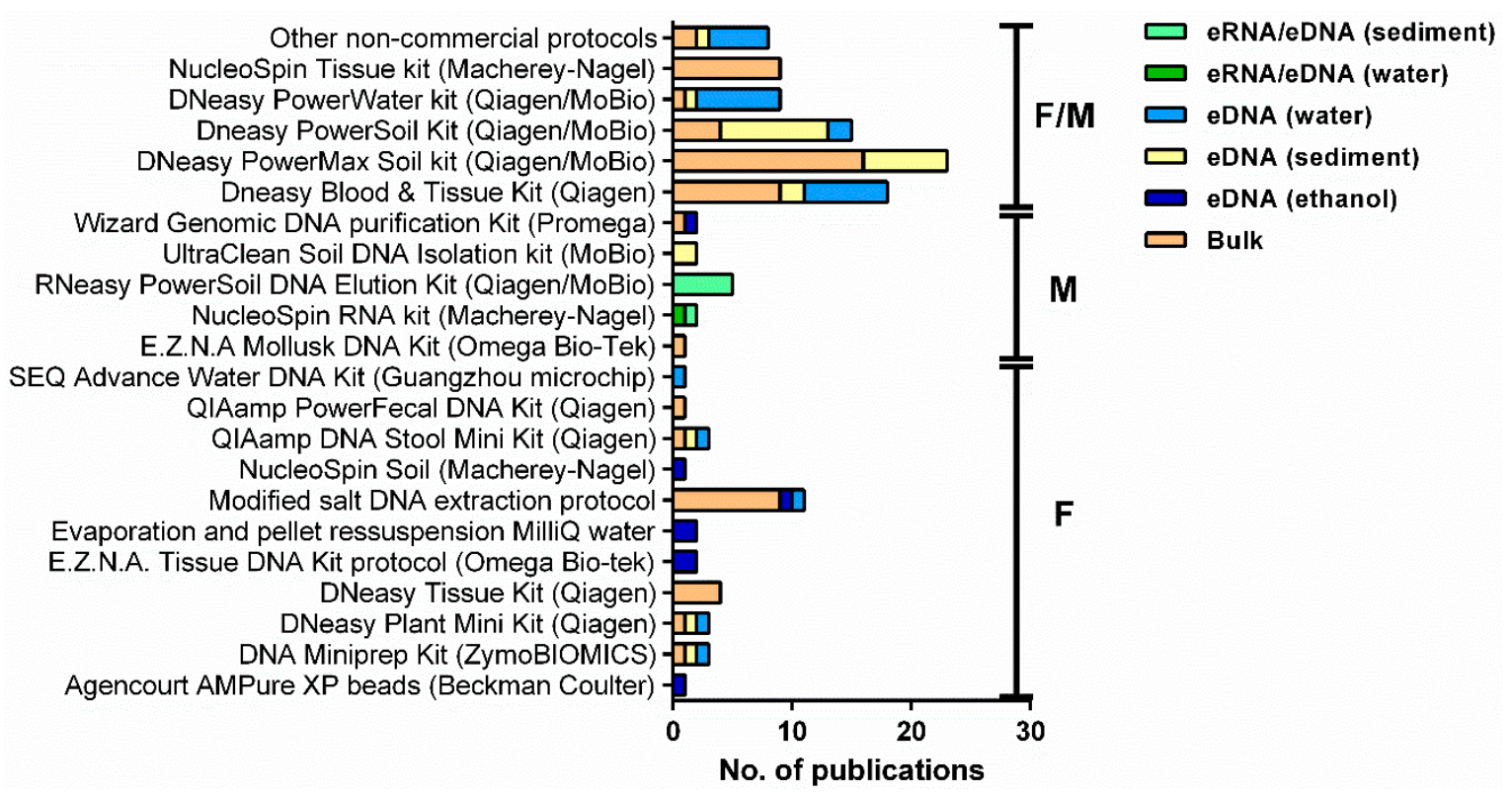

Figure 4. DNA extraction methodologies used for assessing macroinvertebrate diversity through metabarcoding in (F) fresh and $(\mathrm{M})$ transitional/marine waters.

On the other hand, non-commercial methods, such as a modified salt DNA extraction protocol, have been widely employed in fresh waters (ca. 23\%, e.g., [23,35,102,112]), which can be more cost-effective than commercial kits and allow any starting amount of material. Other less used protocols included the phenol-chloroform DNA extraction protocol $[57,98]$ and the cetrimonium bromide (CTAB) protocol $[57,119]$ (Table S2). However, non-commercial methods often involve extra purification steps (e.g., [23,102,112]), while DNA yields from commercial kits are usually of high quality [36,104]. In addition, the use of commercial kits has also the advantage of achieving results quickly due to shortened isolation steps, the handling of smaller amounts of chemicals, and being more prone to standardization among different labs and researchers [36]. The use of DNA extraction protocols adapted to 96-well microplates can highly increase sample throughput while reducing the risk of cross-contamination $[89,113]$ and has been proposed to scale-up DNA metabarcoding for the routine monitoring of freshwater macroinvertebrate communities [52].

A few studies had extracted directly the DNA from preservative ethanol in order to characterize macroinvertebrate communities (e.g., $[31,37,43,99,104,109])$. This alternative can greatly speed up processing times in the laboratory before DNA metabarcoding because the decanting and the sorting steps can be much reduced. In fresh waters, communities assessed from preservative ethanol have been found either to display a high overlap with morphology-based analyses and bulk DNA $[31,104]$ but affected by the preservation time and the DNA extraction method employed [104] or to display very different communities [99] or fewer taxa, in particular those with low biomass [109]. In marine waters, Derycke et al. [43] also found a substantially lower number of species in preservative ethanol, with larger size species and soft bodies (without chitin or $\mathrm{CaCO}_{3}$ in their skeletons) displaying higher detection rates. In fresh waters, although Zizka et al. [99] were able to detect most species from a mock community in the ethanol used for preservation, they were not able to reliably detect all Mollusca taxa. Thus, for a comprehensive assessment of the macroinvertebrate diversity in both fresh and marine waters, conventional bulk sample metabarcoding should be rather applied because taxa detection in preservative ethanol may not be sufficient and be greatly influenced by the differences in the morphological traits of the species constituting the communities $[43,99]$. Non-destructive methods, which involve a temporary immersion of whole specimens in an extraction buffer without previous homogenization, may provide comparable results to tissue-based DNA extraction 
methods, and are faster while preserving specimens for taxonomic characterization or individual-based DNA barcoding [101]. In addition, these are not dependent on ethanol quality, usage, or storage time, and may be less influenced by the morphological traits (i.e., size, protective case, and sclerotization) of the species [101]. Non-destructive methods can be of great use for benchmarking metabarcoding against morphology and completing macrozoobenthic inventories while the reference libraries are not completed.

\subsubsection{Marker Loci and Primer Pairs}

Partial segments of the mitochondrial cytochrome c oxidase subunit I (COI) gene have been the most used for targeting benthic macroinvertebrate communities in all typologies of aquatic ecosystems surveyed in the current review (Figure 5). Indeed, it is by far the marker for which a higher coverage exists in reference sequence databases for aquatic macroinvertebrate taxa, including marine and freshwater species [48,49,73,129]. In addition, it has enough genetic variation to allow species level identifications for most taxonomic groups, even when short fragments of ca. 150 bp have been employed [51,100,130,131]. Generally, a higher coverage has been found for freshwater invertebrates (ca. 65\%, [48]) than for marine invertebrates (ca. 22\% to 48\%, [48]) in both the Barcode of Life Data System (BOLD) and GenBank, but coverage strongly varies among taxonomic groups [48]. For instance, Odonata, Trichoptera, and Hemiptera, and crustaceans, have been found to be the best-covered groups among freshwater invertebrates $(\geq 85 \%,[48])$, while marine Annelida, Mollusca, and Arthropoda, which are the most well-represented phyla among marine invertebrates, have completion levels between $40 \%$ to $50 \%$ [48].

Among the COI, the primer pair $\mathrm{mICOIintF/jgHCO2198,} \mathrm{targeting} \mathrm{the} 3^{\prime}$ region, has been by far the most widely used, in particular in marine waters (ca. 34\%, Supplementary Materials: Table S3). This combination of degenerate primers, targeting a fragment of $313 \mathrm{bp}$, performs well across metazoan diversity, with higher success rates than the combination of the forward primer either with HCO2198 or dgHCO2198 reverse primers $[43,132]$. In particular, in marine ecosystems, macrobenthic communities are complex and highly diverse, and primer-sequence mismatches can be often found for several organisms, and thus, degenerate primers may perform better $[43,132,133]$. Although less used, the combination of primers mICOIintF/LoboR1 [132,133] has been tested successfully in mock communities $[15,131]$ and shown to perform just as well as the pair mICOIintF/jgHCO2198 [134]. Moreover, compared to jgHCO2198, LoboR1 has the advantage of lacking inosine bases, which may be incompatible with high-fidelity Taq polymerases usually employed for amplifying the PCR amplicons to be high-throughput sequenced, and it is also a cost-effective solution $[135,136]$. On the other hand, the amplification of the whole COI region (i.e., barcode region) or of the $5^{\prime}$ region have been less used and reported to recover fewer invertebrate taxa than primers amplifying the $3^{\prime}$ end of the barcode region $[15,43,131,132]$ (Table S3).

In fresh waters, four highly degenerated primer pairs (BF/BR) have been specifically designed for freshwater macrozoobenthos and successfully evaluated using mock communities [112,137]. In particular, the pair BF2/BR2, also targeting the $3^{\prime}$ end of the barcode region, perform particularly well for freshwater insects (up to $100 \%$ of the insects and $98 \%$ of all morphotaxa, respectively, composing 10 different mock communities [137]). Consequently, it has been currently widely employed in environment-derived samples (ca. $21 \%$, Table S3, e.g., [102,112,119]), but showed poor performance on non-insect metazoans such as Bivalvia, Turbellaria, Amphipoda, and Hirudinea [137]).

In marine waters, the nuclear small subunit 18S rRNA (18S) gene has been also widely used, particularly in studies also targeting microbial eukaryotic diversity (Table S2, e.g., $[38,39,56,58,78])$, but to a lesser extent for macroinvertebrates assessment in fresh [37,60,92] and marine [22] waters. Although amplification success may be high due to low variation in primer binding sites, the species level resolution has been found to be substantially lower for $18 \mathrm{~S}$ than for COI [22]. 


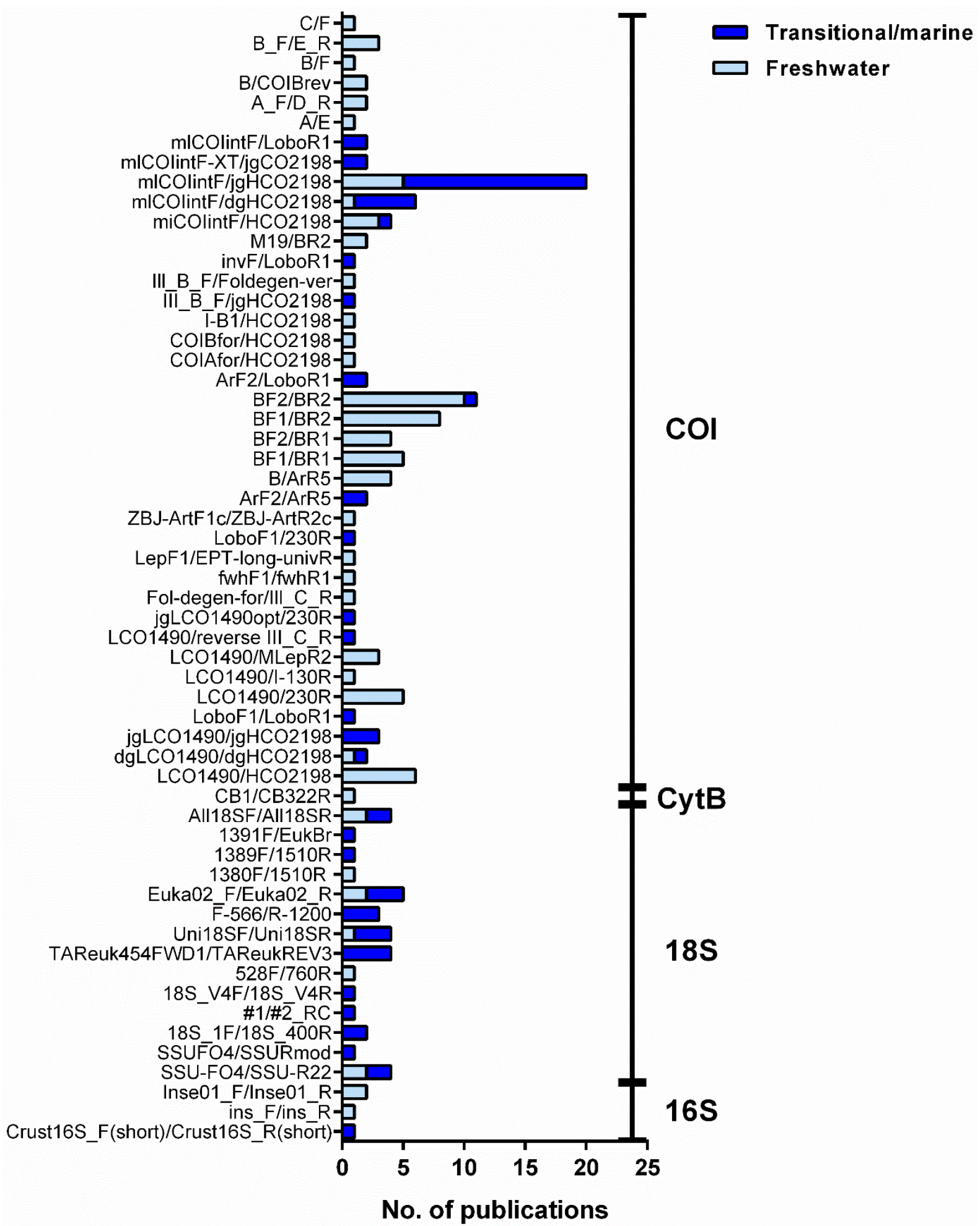

Figure 5. Marker loci and primer pairs used for assessing benthic macroinvertebrate diversity through metabarcoding in fresh and transitional/marine waters. Please see Supplementary Materials: Table S3, for more details of each primer pair (i.e., loci region and fragment length).

Because different markers can yield different diversity estimates [37,43], combining different markers would increase recovered diversity, but only nine studies in marine waters employed COI and other markers (Supplementary Materials: Table S2; 18S, e.g., $[22,56,71,84,87]$ and $16 \mathrm{~S},[56])$, and in fresh waters, only four employed other markers in addition to COI (Table S2; 18S, [37,122,138]; 16S, [37,138]; and CytB, [100]). According to 
Elbrecht et al. [124], the ribosomal marker $16 \mathrm{~S}$ may lead to less biased estimates of biomass than COI but has a low taxonomic resolution, and reference libraries may lack adequate data to support taxonomic identifications [124].

The choice of the primers can highly affect the recovered diversity through metabarcoding approaches because metabarcoding results can be particularly affected by the affinity of the primers with the target sequences [78,80,93], the completeness of reference libraries [80] and reference databases used, and the algorithms used to assign taxonomy [43]. If possible, in silico evaluations and the use of mock communities of known compositions should be used to validate the primers that work better for the target groups and the purpose of the study $[72,137,138]$. For instance, in marine waters, the DNA from mollusks has been reportedly found to have poor mismatches with broad-coverage primers targeting both COI $[80,93,139]$ and $18 S$ [78] regions, but Cowart et al. [22] found a high success of mollusks detection through DNA metabarcoding by using Folmer primers (LCO1490/HCO21982). Marine polychaetes are also a well-known class to display a high diversity in the COI gene [140], and whose amplification may fail even when using different primers [43]. In fresh waters, broad-coverage COI markers are also reported to miss several non-insect taxa such as Mollusca, Annelida, and Platyhelminthes (e.g., [37,59,99]), and high primer degeneracy leads to the best amplification of freshwater and insect taxa [137].

Although the choice of the primers has been found to influence considerably taxa detection, few studies made thorough comparisons (e.g., transitional/marine, [15,43,131] and fresh waters, $[137,141])$. By using marine invertebrate mock communities, Hollatz et al. [131] found that only $30 \%$ to $60 \%$ of all species were recovered by using any single primer set targeting the COI region, while $85 \%$ of the species were detected only when employing at least three primer pairs. Lobo et al. [15] also found that high success rates of detection of estuarine macroinvertebrate taxa were attained when using at least two primer pairs targeting the COI region. In metabarcoding-based surveys of macroinvertebrate taxa in fresh waters, Hajibabaei et al. [141] also found that the combined use of multiple COI amplicons recovered higher taxa richness. Gene enrichment may be an alternative to avoid primer-associated amplification biases but is much less adopted in biomonitoring due to the high cost of probes and increased library preparation time [85]. The design of primers customized to specific taxonomic groups (e.g., Mollusca, Annelida, and Arthropoda), may be a cost-effective solution to avoid biases of broad-coverage primers and to meet the stringent taxonomic requirements when targeting different benthic macroinvertebrate phyla in aquatic ecosystems $[56,142]$.

\subsubsection{Employment of Controls and Validation with Morphology}

The employment of controls along the complete experimental workflow is essential for assessing the validity of the metabarcoding approach. Controls expose two common types of experimental errors-type-I errors (false positives) and type-II errors (false negatives) [143]. Most studies in any of the aquatic ecosystems have been employing negative controls to expose possible sample contamination (Table S2). They include controls applied either since the very beginning of the workflow (i.e., sampling) through the high-throughput sequencing or dedicated to specific steps of the analytical chain. The former controls are often employed in studies analyzing water eDNA because it involves a filtration step that is often conducted in the field and therefore more exposed to potential contamination (e.g., $[64,70,75,102,115,119,122,127])$. The later controls are usually introduced during DNA extraction (e.g., $[36,77,81,127])$ and PCR (e.g., [63,72,104,115,116]) to expose contamination that can originate from extraction buffers and solutions, PCR reagents, and labware. In contrast, negative controls have been less used during laboratorial pre-processing steps of bulk samples in the lab, but the application of muffled sand (i.e., $400{ }^{\circ} \mathrm{C}, 24 \mathrm{~h}$ to remove DNA traces), which is processed alongside regular samples, can help detect contamination or artifacts that may be introduced during pre-processing steps (i.e., sieving, [71,84,116]). 
The employment of mock communities, either by extracting DNA from known combinations of species (e.g., $[15,35,36,99,107,112,125,131,137])$ or by mixing DNA extracts from known species $[37,60,94,98,105,124]$, has been widely used to assess the efficiency of the DNA amplification and sequencing or to establish thresholds (e.g., sequence similarity and minimum read number) for detecting species [24]. They are crucial to understand the prevalence of false negatives, due to methodological limitations, as for example, the inefficiency of DNA extraction protocols (e.g., $[15,31,59,87,100,112,125])$, primer-associated amplification bias (e.g., $[37,60,72,98,115,122,124,131,137])$ and faulty reproducibility of the sequencing process, and gaps in bioinformatic pipelines (e.g., random sampling of rare OTUs, [98]) and reference databases [38,94]. PCR inhibition controls may also be applied to ensure that extracted DNA is free of inhibitors $[35,60,115]$. One possibility consists in the introduction of a known amount of DNA from a non-target species in the DNA template prior to amplification [72]. The introduced DNA must be from an organism very unlikely to occur in the surveyed environment [72], or made of artificially synthesized DNA and known a priori to amplify with the primers in use.

Most of the studies here analyzed also implemented concomitant morphological analyses, which can act as a positive control and are crucial to evaluate the ability of metabarcoding to recover the taxonomic diversity in the samples (e.g., $[15,22,24,27,31,35,38$, $54,100,103,106,113,114])$. However, many morphological identifications are only achieved at order [31] or family level [59]. In order to circumvent this, many studies also DNA barcoded individual specimens, thereby providing low-rank taxonomic assignments (i.e., genus, species) and allowing a better assessment of the metabarcoding efficiency, concurrently completing local reference barcode libraries to increase the success of taxonomic assignments [24,31,41,77,93,100,114,124,125,144].

In most studies, the outcomes of the bioassessments were comparable and complementary to current morphology-based protocols $[23,38,59,63,69,72,80,83,106]$, but the diversity recovered through metabarcoding often exceeded the morphology-based surveys, in particular in marine waters $[15,22,54,82,111]$. A higher degree of resolution, both at taxonomic level $[54,59,67,89,91,131]$ and environmental or geographic level $[61,81,111]$, is often achieved. In most studies, the molecular data also closely matched morphology-based indices $[27,70,78,79,110]$.

Because primer efficiency is highly species-specific, this should impede straightforward assessments of species abundance and biomass through metabarcoding [35]. Indeed, the ability to infer relative species abundances or biomass from metabarcoding data has been fairly disputed among studies. In contrast to some report data suggesting that relative abundance information may be captured with metabarcoding $[27,66,86,93,144]$, others failed to detect any relationship between read number and relative abundance or absolute abundances (e.g., $[15,35,131])$.

\subsubsection{Sequencing Platforms}

Concerning the sequencing platforms used, Illumina (San Diego, CA, USA) is by far the most employed in all typologies of aquatic ecosystems (ca. 74\% of all the studies, Figure 6, Table S2), followed by Roche 454 (Brandford, CT, USA, no longer available), in particular in earlier studies using DNA metabarcoding (e.g., [24,31,58]), and Ion Torrent (Gilford, NH, USA), more frequently used in transitional/marine waters (Figure 6, Table S2). Very few studies compared the efficiency of different platforms, and the ones who did have found either discrepant (e.g., Roche 454 versus Ion Torrent [145]) or similar results (e.g., Illumina versus Ion Torrent [146]) in the diversity recovered. 


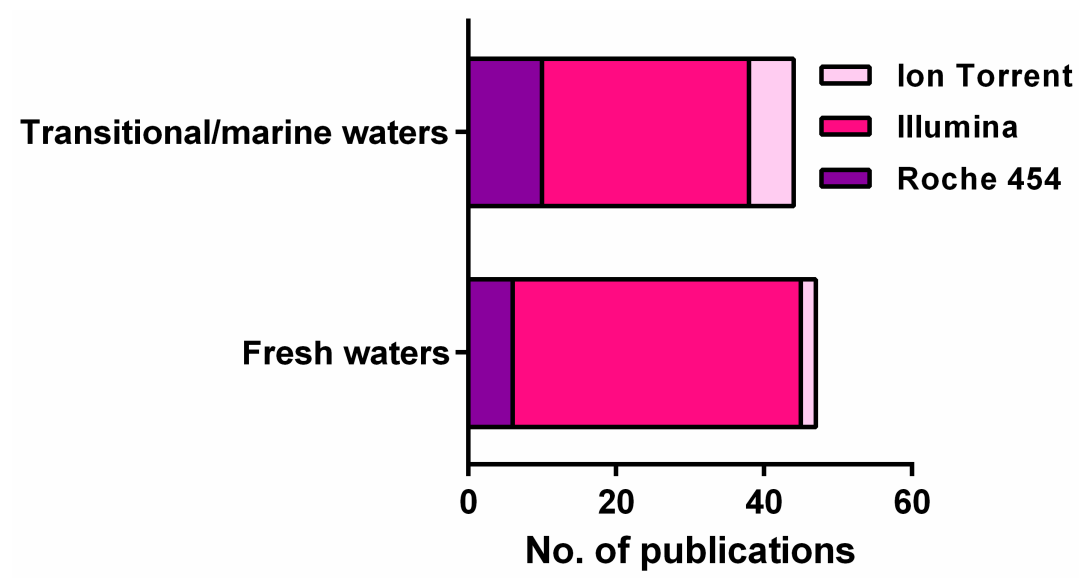

Figure 6. Sequencing platforms used for assessing macroinvertebrate diversity through metabarcoding in fresh and transitional/marine waters.

Among Illumina platforms, MiSeq is clearly the most frequently used (Table S2), but a recent study found that the newest platform from Illumina-NovaSeq-was able to detect many more taxa than the former in marine waters, even when the same sequencing depth was employed [147]. While a meaningful difference may be found in the detection of biota from eDNA in a complex environment such as the open ocean or the deep-sea, in lower diversity realms such as fresh or transitional waters, or if bulk samples are analyzed, these differences may be minor and can be compensated by increasing the sequencing depth. In addition, NovaSeq is still too expensive for most labs (10 times more expensive than MiSeq [147]), and cost-effective solutions need to be found, in particular as metabarcoding is routinely implemented.

A cost-effective solution may be provided by Oxford Nanopore (Oxford, UK) or PacBio (Menlo Park, CA, USA) platforms [135,148]. For instance, in a study employing ARMS in marine ecosystems biomonitoring, MinION (small handheld sequencer from Oxford Nanopore) barcodes, generated from macrofaunal samples (the fraction $>2 \mathrm{~mm}$ ) were highly accurate compared to Illumina reference barcodes [135]. In addition, data were available within $3.5-4 \mathrm{~h}$, and at a lower price, but it still remains presently untested in metabarcoding and no established pipeline exists yet for metazoans [135]. On the downside, Oxford Nanopore and PacBio platforms are reported to have lower raw read accuracy than Illumina, but something that can be compensated by the ability to generate longer reads (ca. $700 \mathrm{bp}$ versus $300 \mathrm{bp}$ generated by Illumina [44]).

\section{Final Considerations and Conclusions}

The use of metabarcoding for assessing benthic macroinvertebrate communities has been proving its efficiency and great potential for improved monitoring of aquatic environments, including marine, transitional, and fresh waters (rivers, streams, ponds, reservoirs, and wetlands). However, whereas for fresh waters several countries are already actively working towards its implementation in routine monitoring of macroinvertebrates, and perhaps with greater feasibility and promptness to complement biomonitoring programs on a large scale $[21,52,137]$, implementation in marine waters appears to be somewhat more challenging and lagging behind, although some broad-scale networks have started to emerge $[80,81,95,117]$. Either in marine or freshwater realms, there are still important shortfalls that need to be addressed by near-future research before a full and dependable transition to molecular approaches is completely accomplished.

A SWOT analysis (Figure 7), which analyses the strengths, weaknesses, opportunities and threats, revealed that the main current weaknesses and threats for the widespread applicability of macrozoobenthos metabarcoding concern with (1) the need for standard and broad implementation protocols, without which scaling up laboratory and field protocols can be compromised, (2) the challenges of completely circumventing PCR amplification bi- 
ases and the still incomplete reference databases, which can lead to incomplete or erroneous species assignments, and, finally, (3) the difficulty in inferring quantitative abundance from metabarcoding data, which is a key component of the most commonly used benthic indices implemented in legal frameworks (e.g., WFD) (Figure 7). Strategies for scaling up laboratory protocols have been already designed and proposed for its use in routine large-scale monitoring projects in fresh waters [52]. In addition, existing indices have been already successfully adapted to infer ecological conditions using sequence-based data in transitional/marine ecosystems (i.e., gAMBI-genetics based AZTI's Marine Biotic Index [27,149]). Recommendations to fulfill reference libraries have been already provided for Europe [48], and this particularly includes targeting the species relevant in biomonitoring programs. In the case of marine invertebrates, this includes the taxa of the AMBI checklist, in particular those more dominant in the datasets, such as Mollusca, Crustacea, and Annelida [2,49,149], while for freshwater macroinvertebrates this includes the groups widely used in WFD monitoring, and especially the most sensitive groups of insects Ephemeroptera, Plecoptera, and Trichoptera, in addition to Crustacea and Mollusca [48]. Filling reference libraries is undoubtedly crucial to support species identifications because it is still the most pointed-out reason for the failure of species detection through DNA metabarcoding in distinct world regions [22,23,38,84,107,109,124]. Ideally, this should include the full sweep of species in the target ecosystem, with a balanced representation of specimens across each species distributional range, which would account for possible regional variability and reveal possible hidden diversity. The audition and annotation of these reference libraries are also of extreme importance to account for accidental errors that may arise from the generation of the sequences and may compromise accurate species identifications [150]. For instance, GenBank contains reference sequences from many different genetic markers, but it is more exposed to errors because it can contain a high number of non-curated entries [82]. Thus, as procedures become optimized and their use more widespread, metabarcoding is becoming an important tool for aquatic ecological monitoring.

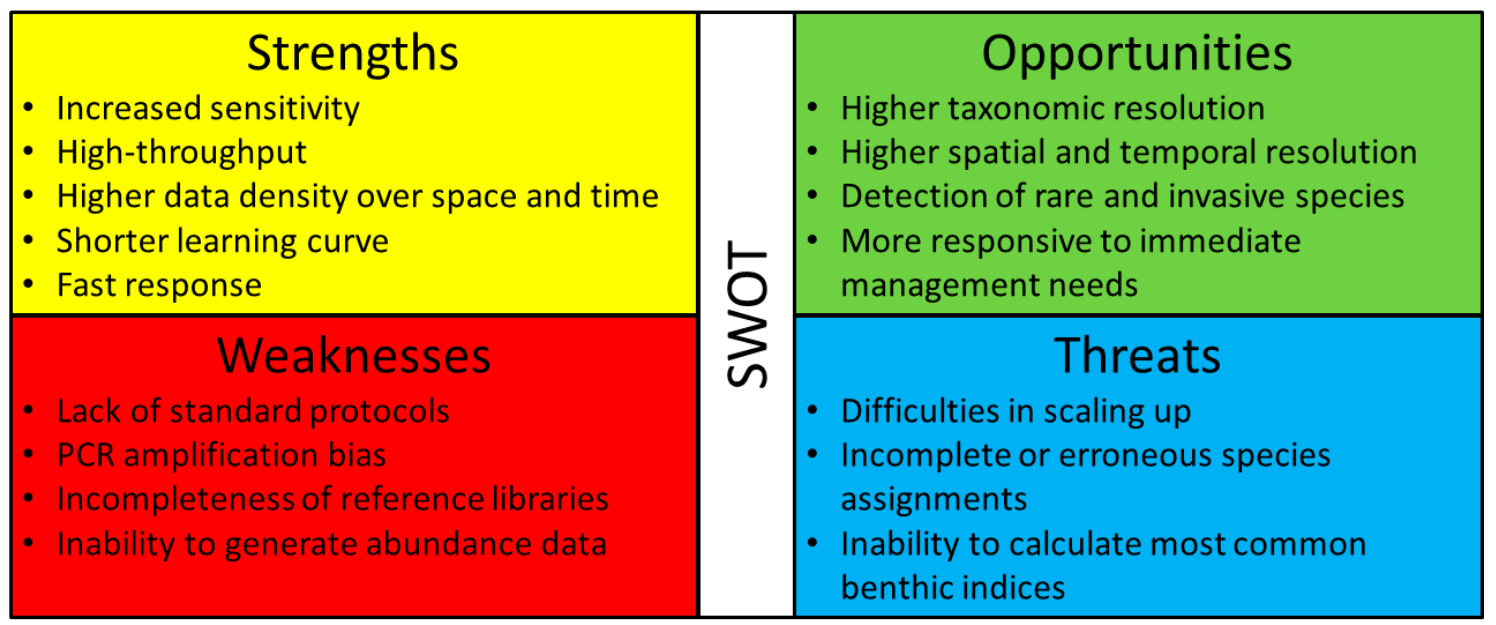

Figure 7. SWOT analysis of the application of DNA metabarcoding in aquatic ecosystems bioassessment using benthic macroinvertebrates.

On the other hand, we identified several strengths and opportunities, compared with morphology-based approaches, including (1) increased sensitivity in species detection and higher taxonomic resolution (i.e., taxonomic identifications typically at species level or at least down to genus), (2) high-throughput approach, which allows to scale up sample processing considerably and increase both spatial and temporal frequency in data acquisition in monitoring programs, and (3) does not require taxonomic expertise (only at the reference library building and alfa taxonomy stage), therefore the response is fast and more prompt to immediate management needs. 
Considering this SWOT analysis and the current status of the development of metabarcoding protocols, we recommend a transition phase involving the implementation of a combined approach where both methods (DNA and morphology) are employed, when possible, in order to successfully and extensively benchmark DNA-based approaches against past long-term monitoring through morphology. Although DNA-based monitoring appears to gradually expand its use, specimen identification based on morphology will probably be still required, at the very least to provide abundance data. One possibility is to continue to perform morphology-based surveys but much more spaced in time and geographic scope than metabarcoding assessments. Furthermore, morphological and other whole-specimen data can contribute much more to ecologically pertinent data beyond basic taxonomic identifications that can have an irreplaceable use in environmental assessments (e.g., size, biomass, morphometries, and functional roles).

We also identified procedures that have been predominantly used along the analytical chain of DNA metabarcoding (excluding bioinformatics pipelines) because of the demonstrated positive influence on the reliability and precision of the results and are thus a good starting point for methodological standardization of aquatic macrozoobenthos monitoring through metabarcoding (Figure 8). These include the following:

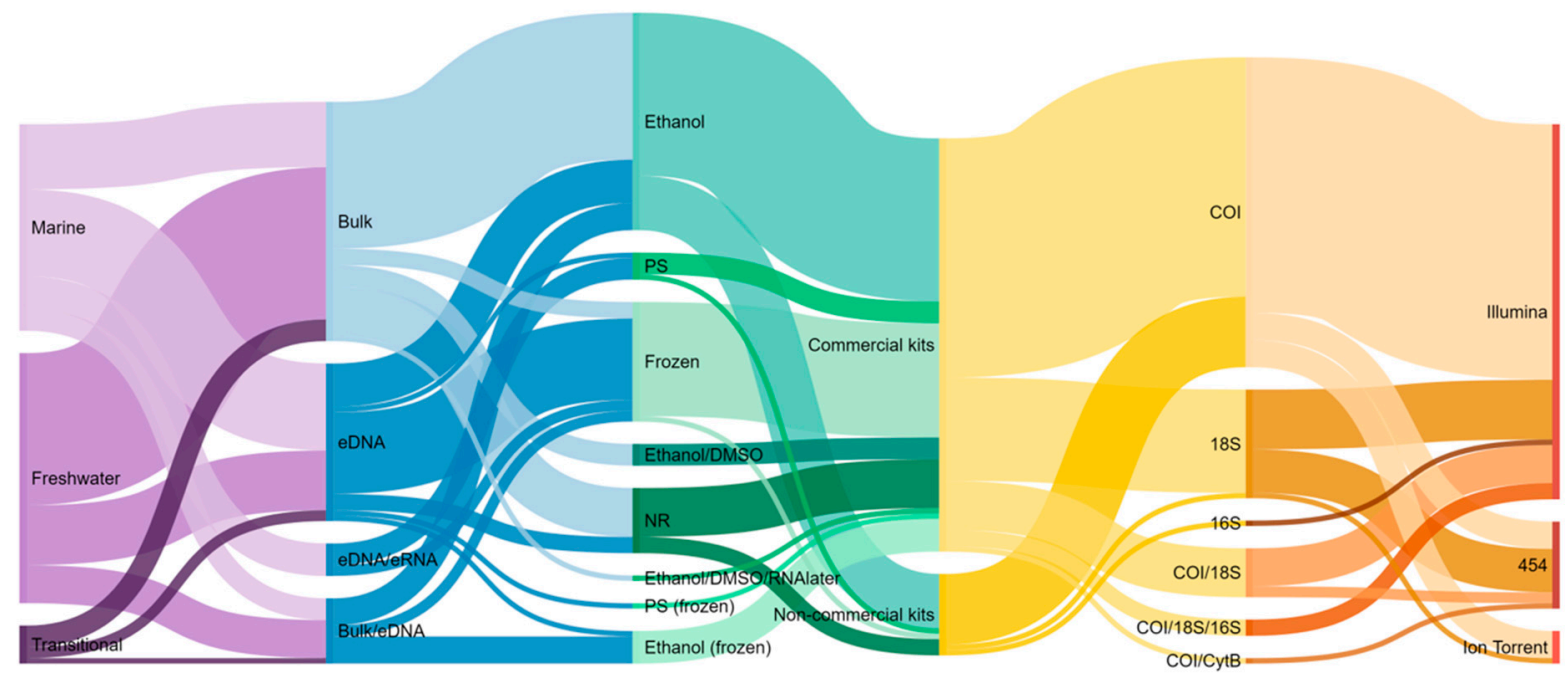

Figure 8. Diagram resuming the methods employed at each stage of the analytical chain of the metabarcoding workflow from the 90 publications analyzed in the current study. The thickness of the lines corresponds to the number of publications using a method. NR represents studies where the corresponding stage/method was not reported and PS represents preservation solution.

- the preferential use of bulk communities if targeting the macrozoobenthos for aquatic assessments, or at the very least the bulk preservative, if specimens are to be kept intact. Indeed, several studies indicated that water and sediment eDNA tend to reflect only partially benthic macroinvertebrate communities, either in marine or fresh waters;

- implementation of experimental/field and/or technical replicates during sampling, DNA extraction, and PCR amplification. This implementation is critical to avoid bias in results, disentangle the effects of technical variance, including false positives (contamination) and false negatives, and increase the capacity of taxa detection in particular of rare species;

- the use of negative and positive controls (e.g., mock communities) all along the metabarcoding analytical chain;

- the use of Ethanol 95-96\% for sample preservation, or DMSO buffer in the particular case of marine sessile fauna retrieved from ARMS;

- the predominant use of DNA isolation kits. In particular, the PowerMax Soil isolation kit allows DNA extraction of samples from either marine or freshwater environments 
and up to $10 \mathrm{~g}$ of biomass, generating high-quality DNA from a wide range of environmental matrices (sediment, water), and from bulk organismal samples with variable phylogenetic compositions. The downside is the high cost of these kits, which may limit the ability to implement metabarcoding-based approaches as extensively as desired, particularly in certain regions of the globe where running costs are highly limiting. Cost-effective alternatives, such as the use of non-commercial protocols (e.g., modified salt DNA extraction) can also be adopted, as long as the high-quality of the DNA extracted, at the end of the step, is ensured. When possible, method validation should be performed with mock communities.

- We highly recommend the use of more than one marker region, and more than one primer pair because freshwater and marine macroinvertebrates are typically phylogenetically diverse. However, in the impossibility of using two markers, priority should be given to COI, which has the broadest coverage in reference libraries, allows identification at the species level for most metazoans, and these are essential in benthic monitoring and for applying many indices based on macroinvertebrate taxa. When possible, in silico evaluations should be conducted, in addition to primer validation with mock communities.

- Finally, standardized sampling is also highly desirable for allowing comparable descriptions of biodiversity in aquatic ecosystems and can also greatly benefit biomonitoring through DNA metabarcoding. In fresh waters, sampling should follow a standardized protocol that is usually implemented for ecological quality assessment based on morphological identifications (i.e., standardization of sampler type and procedure, mesh size, sampling period, distribution of sub-samples by instream habitats, and sub-sampling methods) [52,151]. Among other possibilities, for assessing hardbottom communities in marine ecosystems, the deployment of artificial structures (e.g., ARMS, ASUs) for fixed periods of time, in combination with DNA metabarcoding, is very promising for achieving long-term or high-frequency monitoring.

In conclusion, the use of metabarcoding in monitoring aquatic ecosystems will continue to require scientific collaboration and coordination among researchers, in particular for calibrating methodologies among different labs [20]. Metabarcoding serves a variety of purposes ranging from water quality to ecosystem conservation and restoration assessments through NIS detection. Its throughput, accuracy, and taxonomic resolution capabilities make it a prime candidate for becoming the workhorse of aquatic biomonitoring during the next years, as morphology-based macroinvertebrate assessments have been so far. However, one of the greatest challenges is related to end-user confidence and legal implementation $[18,152,153]$. For this reason, it is vital that end-users recognize the power and the limitations of existing tools, to know how (e)DNA metabarcoding works and what it can offer beyond existing methods, and what are the limitations of the technique [153]. Because there are key differences between metabarcoding and morphology-based approaches (e.g., detection capability and taxonomic resolution versus capturing species abundance data), extensive benchmarking of the former against the latter is needed to understand the impact of these differences in the outcomes of the bioassessments, especially when one considers the long-term bioassessments generated using the morphological approach along the past decades.

Lastly, it is indispensable that manuals be created with information on how the tool should be best used, accounting for error minimization and quantification, how to interpret the results, and how they can influence decisions on best practices and decision-support frameworks [21,153]. Clear communication among the diverse partners involved (researchers and managers) in all stages of the research (i.e., protocols definition, samples collection, laboratory analyses, data analyses, and result interpretation) would be also essential for a successful implementation of molecular methods in biomonitoring [152].

Supplementary Materials: The following are available online at https: / / www.mdpi.com/2073-4 441/13/3/331/s1, Table S1: List of publications used to retrieve the information used to conduct 
the current review. * Publications added by the authors that were not retrieved during the search, Table S2: References and information retrieved from the 90 publications employing DNA metabarcoding in aquatic ecosystems biomonitoring using benthic macroinvertebrates, Table S3: Markers loci and targeted specific regions within each locus, primer pairs, and approximate fragments length (bp) and no. of studies that used each primer pair in (F) fresh waters and (M) transitional/marine waters.

Author Contributions: Conceptualization, A.F.F., F.O.C., M.J.F., and S.D.; methodology, A.F.F., B.R.L., and S.D.; formal analysis, A.F.F., B.R.L., and S.D.; writing—original draft preparation, A.F.F., B.R.L., F.O.C., and S.D.; writing-review and editing, A.F.F., B.R.L., F.O.C., M.J.F., and S.D.; visualization, A.F.F., B.R.L., and S.D. All authors have read and agreed to the published version of the manuscript.

Funding: This work was supported by the "Contrato-Programa" UIDB/04050/2020 and the project NIS-DNA (PTDC/BIA-BMA/29754/2017) funded by national funds through the FCT I.P (Foundation for Science and Technology). Financial support granted by the FCT to S.D. (CEECIND/00667/2017) and B.R.L. (PD/BD/127994/2016) is also acknowledged. A.F.F. was supported by the project FRESHING founded by the FCT and COMPETE (PTDC/AAGMAA/2261/2014-POCI-01-0145-FEDER356016824). M.J.F. was supported by FCT through MARE strategic project UIDB/04292/2020 and Norma Transitória-DL57/2016.

Data Availability Statement: All the data analyzed in this review is provided in the Supplementary Materials.

Conflicts of Interest: The authors declare no conflict of interest.

\section{References}

1. Baird, D.J.; Hajibabaei, M. Biomonitoring 2.0: A New Paradigm in Ecosystem Assessment Made Possible by next-Generation DNA Sequencing. Mol. Ecol. 2012, 21, 2039-2044. [CrossRef] [PubMed]

2. Borja, A.; Franco, J.; Perez Landa, V. A Marine Biotic Index to Establish the Ecological Quality of Soft-Bottom Benthos Within European Estuarine and Coastal Environments. Mar. Pollut. Bull. 2000, 40, 1100-1114. [CrossRef]

3. Filipe, A.F.; Feio, M.J.; Garcia-Raventós, A.; Ramião, J.P.; Pace, G.; Martins, F.M.; Magalhães, M.F. The European Water Framework Directive Facing Current Challenges: Recommendations for a More Efficient Biological Assessment of Inland Surface Waters. Inland Waters 2019, 9, 95-103. [CrossRef]

4. Feio, M.J.; Ferreira, J.; Buffagni, A.; Erba, S.; Dörflinger, G.; Ferréol, M.; Munné, A.; Prat, N.; Tziortzis, I.; Urbanič, G. Comparability of Ecological Quality Boundaries in the Mediterranean Basin Using Freshwater Benthic Invertebrates. Statistical Options and Implications. Sci. Total Environ. 2014, 476-477, 777-784. [CrossRef]

5. $\quad$ Feio, M.J.; Aguiar, F.C.; Almeida, S.F.P.; Ferreira, J.; Ferreira, M.T.; Elias, C.; Serra, S.R.Q.; Buffagni, A.; Cambra, J.; Chauvin, C.; et al. Least Disturbed Condition for European Mediterranean Rivers. Sci. Total Environ. 2014, 476-477, 745-756. [CrossRef]

6. Birk, S.; Bonne, W.; Borja, A.; Brucet, S.; Courrat, A.; Poikane, S.; Solimini, A.; van de Bund, W.; Zampoukas, N.; Hering, D. Three Hundred Ways to Assess Europe's Surface Waters: An Almost Complete Overview of Biological Methods to Implement the Water Framework Directive. Ecol. Indic. 2012, 18, 31-41. [CrossRef]

7. Borja, A.; Elliott, M.; Andersen, J.H.; Cardoso, A.C.; Carstensen, J.; Ferreira, J.G.; Heiskanen, A.-S.; Marques, J.C.; Neto, J.M.; Teixeira, H.; et al. Good Environmental Status of Marine Ecosystems: What Is It and How Do We Know When We Have Attained It? Mar. Pollut. Bull. 2013, 76, 16-27. [CrossRef]

8. Bonada, N.; Prat, N.; Resh, V.H.; Statzner, B. Developments in Aquatic Insect Biomonitoring: A Comparative Analysis of Recent Approaches. Annu. Rev. Entomol. 2006, 51, 495-523. [CrossRef]

9. Teixeira, H.; Salas, F.; Borja, Á.; Neto, J.M.; Marques, J.C. A Benthic Perspective in Assessing the Ecological Status of Estuaries: The Case of the Mondego Estuary (Portugal). Ecol. Indic. 2008, 8, 404-416. [CrossRef]

10. Covich, A.P.; Palmer, M.A.; Crowl, T.A. The Role of Benthic Invertebrate Species in Freshwater Ecosystems: Zoobenthic Species Influence Energy Flows and Nutrient Cycling. BioScience 1999, 49, 119-127. [CrossRef]

11. Salas, F.; Neto, J.M.; Borja, A.; Marques, J.C. Evaluation of the Applicability of a Marine Biotic Index to Characterize the Status of Estuarine Ecosystems: The Case of Mondego Estuary (Portugal). Ecol. Indic. 2004, 4, 215-225. [CrossRef]

12. Hering, D.; Borja, A.; Carstensen, J.; Carvalho, L.; Elliott, M.; Feld, C.K.; Heiskanen, A.-S.; Johnson, R.K.; Moe, J.; Pont, D.; et al. The European Water Framework Directive at the Age of 10: A Critical Review of the Achievements with Recommendations for the Future. Sci. Total Environ. 2010, 408, 4007-4019. [CrossRef] [PubMed]

13. Borja, A.; Miles, A.; Occhipinti-Ambrogi, A.; Berg, T. Current Status of Macroinvertebrate Methods Used for Assessing the Quality of European Marine Waters: Implementing the Water Framework Directive. Hydrobiologia 2009, 633, 181-196. [CrossRef]

14. Yu, D.W.; Ji, Y.; Emerson, B.C.; Wang, X.; Ye, C.; Yang, C.; Ding, Z. Biodiversity Soup: Metabarcoding of Arthropods for Rapid Biodiversity Assessment and Biomonitoring. Methods Ecol. Evol. 2012, 3, 613-623. [CrossRef]

15. Lobo, J.; Shokralla, S.; Costa, M.H.; Hajibabaei, M.; Costa, F.O. DNA Metabarcoding for High-Throughput Monitoring of Estuarine Macrobenthic Communities. Sci. Rep. 2017, 7, 15618. [CrossRef] [PubMed] 
16. Borja, A.; Elliott, M.; Andersen, J.H.; Berg, T.; Carstensen, J.; Halpern, B.S.; Heiskanen, A.-S.; Korpinen, S.; Lowndes, J.S.S.; Martin, G.; et al. Overview of Integrative Assessment of Marine Systems: The Ecosystem Approach in Practice. Front. Mar. Sci. 2016, 3. [CrossRef]

17. Costello, M.J.; Basher, Z.; McLeod, L.; Asaad, I.; Claus, S.; Vandepitte, L.; Yasuhara, M.; Gislason, H.; Edwards, M.; Appeltans, W.; et al. Methods for the Study of Marine Biodiversity. In The GEO Handbook on Biodiversity Observation Networks; Walters, M., Scholes, R.J., Eds.; Springer International Publishing: Cham, Switzerland, 2017; pp. 129-163, ISBN 978-3-319-27288-7.

18. Hering, D.; Borja, A.; Jones, J.I.; Pont, D.; Boets, P.; Bouchez, A.; Bruce, K.; Drakare, S.; Hänfling, B.; Kahlert, M.; et al. Implementation Options for DNA-Based Identification into Ecological Status Assessment under the European Water Framework Directive. Water Res. 2018, 138, 192-205. [CrossRef]

19. Shokralla, S.; Spall, J.L.; Gibson, J.F.; Hajibabaei, M. Next-Generation Sequencing Technologies for Environmental DNA Research. Mol. Ecol. 2012, 21, 1794-1805. [CrossRef]

20. Blackman, R.C.; Mächler, E.; Altermatt, F.; Arnold, A.; Beja, P.; Boets, P.; Egeter, B.; Elbrecht, V.; Filipe, A.F.; Jones, J.I.; et al. Advancing the Use of Molecular Methods for Routine Freshwater Macroinvertebrate Biomonitoring-the Need for Calibration Experiments. Metabarcoding Metagenom. 2019, 3, e34735. [CrossRef]

21. Leese, F.; Bouchez, A.; Abarenkov, K.; Altermatt, F.; Borja, Á.; Bruce, K.; Ekrem, T.; Čiampor, F.; Čiamporová-Zat'ovičová, Z.; Costa, F.O.; et al. Chapter Two-Why We Need Sustainable Networks Bridging Countries, Disciplines, Cultures and Generations for Aquatic Biomonitoring 2.0: A Perspective Derived From the DNAqua-Net COST Action. In Advances in Ecological Research; Bohan, D.A., Dumbrell, A.J., Woodward, G., Jackson, M., Eds.; Next Generation Biomonitoring: Part 1; Academic Press: Cambridge, MA, USA, 2018; Volume 58, pp. 63-99.

22. Cowart, D.A.; Pinheiro, M.; Mouchel, O.; Maguer, M.; Grall, J.; Miné, J.; Arnaud-Haond, S. Metabarcoding Is Powerful yet Still Blind: A Comparative Analysis of Morphological and Molecular Surveys of Seagrass Communities. PLoS ONE $2015,26$.

23. Elbrecht, V.; Vamos, E.E.; Meissner, K.; Aroviita, J.; Leese, F. Assessing Strengths and Weaknesses of DNA Metabarcoding-based Macroinvertebrate Identification for Routine Stream Monitoring. Methods Ecol. Evol. 2017, 8, 1265-1275. [CrossRef]

24. Hajibabaei, M.; Shokralla, S.; Zhou, X.; Singer, G.A.C.; Baird, D.J. Environmental Barcoding: A Next-Generation Sequencing Approach for Biomonitoring Applications Using River Benthos. PLoS ONE 2011, 6, e17497. [CrossRef] [PubMed]

25. Cristescu, M.E. From Barcoding Single Individuals to Metabarcoding Biological Communities: Towards an Integrative Approach to the Study of Global Biodiversity. Trends Ecol. Evol. 2014, 29, 566-571. [CrossRef] [PubMed]

26. Leese, F.; Altermatt, F.; Bouchez, A.; Ekrem, T.; Hering, D.; Meissner, K.; Mergen, P.; Pawlowski, J.; Piggott, J.; Rimet, F.; et al. DNAqua-Net: Developing New Genetic Tools for Bioassessment and Monitoring of Aquatic Ecosystems in Europe. Res. Ideas Outcomes 2016, 2, e11321. [CrossRef]

27. Aylagas, E.; Borja, Á.; Muxika, I.; Rodríguez-Ezpeleta, N. Adapting Metabarcoding-Based Benthic Biomonitoring into Routine Marine Ecological Status Assessment Networks. Ecol. Indic. 2018, 95, 194-202. [CrossRef]

28. Hebert, P.; Cywinska, A.; Ball, S.L.; Dewaard, J. Biological Identification through DNA Barcodes. Proc. R. Soc. Lond. B 2003, 270, 313-321. [CrossRef]

29. Costa, F.O.; Antunes, P.M. The Contribution of the Barcode of Life Initiative to the Discovery and Monitoring of Biodiversity. In Natural Resources, Sustainability and Humanity: A Comprehensive View; Mendonca, A., Cunha, A., Chakrabarti, R., Eds.; Springer: Dordrecht, The Netherlands, 2012; pp. 37-68. ISBN 978-94-007-1321-5.

30. Taberlet, P.; Coissac, E.; Pompanon, F.; Brochmann, C.; Willerslev, E. Towards Next-Generation Biodiversity Assessment Using DNA Metabarcoding. Mol. Ecol. 2012, 21, 2045-2050. [CrossRef]

31. Hajibabaei, M.; Spall, J.L.; Shokralla, S.; van Konynenburg, S. Assessing Biodiversity of a Freshwater Benthic Macroinvertebrate Community through Non-Destructive Environmental Barcoding of DNA from Preservative Ethanol. BMC Ecol. $2012,12,28$. [CrossRef]

32. Pawlowski, J.; Kelly-Quinn, M.; Altermatt, F.; Apothéloz-Perret-Gentil, L.; Beja, P.; Boggero, A.; Borja, A.; Bouchez, A.; Cordier, T.; Domaizon, I.; et al. The Future of Biotic Indices in the Ecogenomic Era: Integrating (e)DNA Metabarcoding in Biological Assessment of Aquatic Ecosystems. Sci. Total Environ. 2018, 637-638, 1295-1310. [CrossRef]

33. Creer, S.; Deiner, K.; Frey, S.; Porazinska, D.; Taberlet, P.; Thomas, W.K.; Potter, C.; Bik, H.M. The Ecologist's Field Guide to Sequence-Based Identification of Biodiversity. Methods Ecol. Evol. 2016, 7, 1008-1018. [CrossRef]

34. Pawlowski, J.; Apothéloz-Perret-Gentil, L.; Altermatt, F. Environmental DNA: What's behind the Term? Clarifying the Terminology and Recommendations for Its Future Use in Biomonitoring. Mol. Ecol. 2020, 29, 4258-4264. [CrossRef] [PubMed]

35. Elbrecht, V.; Leese, F. Can DNA-Based Ecosystem Assessments Quantify Species Abundance? Testing Primer Bias and BiomassSequence Relationships with an Innovative Metabarcoding Protocol. PLoS ONE 2015, 10, e0130324. [CrossRef] [PubMed]

36. Hermans, S.M.; Buckley, H.L.; Lear, G. Optimal Extraction Methods for the Simultaneous Analysis of DNA from Diverse Organisms and Sample Types. Mol. Ecol. Resour. 2018, 18, 557-569. [CrossRef]

37. Martins, F.M.S.; Porto, M.; Feio, M.J.; Egeter, B.; Bonin, A.; Serra, S.R.Q.; Taberlet, P.; Beja, P. Modelling Technical and Biological Biases in Macroinvertebrate Community Assessment from Bulk Preservative Using Multiple Metabarcoding Markers. Mol. Ecol. 2020. [CrossRef] [PubMed]

38. Steyaert, M.; Priestley, V.; Osborne, O.; Herraiz, A.; Arnold, R.; Savolainen, V. Advances in Metabarcoding Techniques Bring Us Closer to Reliable Monitoring of the Marine Benthos. J. Appl. Ecol. 2020, 57, 2234-2245. [CrossRef] 
39. Chariton, A.A.; Stephenson, S.; Morgan, M.J.; Steven, A.D.L.; Colloff, M.J.; Court, L.N.; Hardy, C.M. Metabarcoding of Benthic Eukaryote Communities Predicts the Ecological Condition of Estuaries. Environ. Pollut. 2015, 203, 165-174. [CrossRef]

40. Lanzén, A.; Lekang, K.; Jonassen, I.; Thompson, E.M.; Troedsson, C. High-Throughput Metabarcoding of Eukaryotic Diversity for Environmental Monitoring of Offshore Oil-Drilling Activities. Mol. Ecol. 2016, 25, 4392-4406. [CrossRef]

41. Ransome, E.; Geller, J.B.; Timmers, M.; Leray, M.; Mahardini, A.; Sembiring, A.; Collins, A.G.; Meyer, C.P. The Importance of Standardization for Biodiversity Comparisons: A Case Study Using Autonomous Reef Monitoring Structures (ARMS) and Metabarcoding to Measure Cryptic Diversity on Mo'orea Coral Reefs, French Polynesia. PLoS ONE 2017, 12, e0175066. [CrossRef]

42. Borrell, Y.J.; Miralles, L.; Mártinez-Marqués, A.; Semeraro, A.; Arias, A.; Carleos, C.E.; García-Vázquez, E. Metabarcoding and Post-Sampling Strategies to Discover Non-Indigenous Species: A Case Study in the Estuaries of the Central South Bay of Biscay. J. Nat. Conserv. 2018, 42, 67-74. [CrossRef]

43. Derycke, S.; Maes, S.; Hillewaert, H.; Ampe, B.; Haegeman, A.; Hostens, K.; De, A. Optimisation of Metabarcoding for Monitoring Marine Macrobenthos: Primer Choice and Morphological Traits Determine Species Detection in BulkDNA and EDNA from the Ethanol Preservative. Authorea 2020. [CrossRef]

44. Van der Loos, L.M.; Nijland, R. Biases in Bulk: DNA Metabarcoding of Marine Communities and the Methodology Involved. Mol. Ecol. 2020. [CrossRef] [PubMed]

45. Duarte, S.; Vieira, P.E.; Lavrador, A.S.; Costa, F.O. Status and Prospects of Marine NIS Detection and Monitoring through (e)DNA Metabarcoding. Sci. Total Environ. 2021, 751, 141729. [CrossRef]

46. Scott, R.; Zhan, A.; Brown, E.A.; Chain, F.J.J; Cristescu, M.E.; Gras, R.; MacIsaac, H.J. Optimization and Performance Testing of a Sequence Processing Pipeline Applied to Detection of Nonindigenous Species. Evol. Appl. 2018, 11, 891-905. [CrossRef] [PubMed]

47. Feio, M.; Filipe, A.; Garcia-Raventós, A.; Ardura, A.; Calapez, A.; Pujante, A.; Mortágua, A.; Múrria, C.; Quijano, D.; Martins, F.; et al. Advances in the Use of Molecular Tools in Ecological and Biodiversity Assessment of Aquatic Ecosystems. Limnetica 2020, 39, 419-440. [CrossRef]

48. Weigand, H.; Beermann, A.J.; Čiampor, F.; Costa, F.O.; Csabai, Z.; Duarte, S.; Geiger, M.F.; Grabowski, M.; Rimet, F.; Rulik, B.; et al. DNA Barcode Reference Libraries for the Monitoring of Aquatic Biota in Europe: Gap-Analysis and Recommendations for Future Work. Sci. Total Environ. 2019, 678, 499-524. [CrossRef] [PubMed]

49. Leite, B.R.; Vieira, P.E.; Teixeira, M.A.L.; Lobo-Arteaga, J.; Hollatz, C.; Borges, L.M.S.; Duarte, S.; Troncoso, J.S.; Costa, F.O. Gap-Analysis and Annotated Reference Library for Supporting Macroinvertebrate Metabarcoding in Atlantic Iberia. Reg. Stud. Mar. Sci. 2020, 36, 101307. [CrossRef]

50. Duarte, S.; Vieira, P.E.; Costa, F.O. Assessment of Species Gaps in DNA Barcode Libraries of Non-Indigenous Species (NIS) Occurring in European Coastal Regions. Metabarcoding Metagenomics 2020, 4, e55162. [CrossRef]

51. Inai, K.; Wakimura, K.; Kato, M. Pairwise Sequence Comparison Data of the DNA Barcodes of Aquatic Insects. Data Brief 2020, 32, 106284. [CrossRef]

52. Elbrecht, V.; Steinke, D. Scaling up DNA Metabarcoding for Freshwater Macrozoobenthos Monitoring. Freshw. Biol. 2019, 64, 380-387. [CrossRef]

53. Callahan, B.J.; McMurdie, P.J.; Holmes, S.P. Exact Sequence Variants Should Replace Operational Taxonomic Units in Marker-Gene Data Analysis. ISME J. 2017, 11, 2639-2643. [CrossRef]

54. Gibson, J.F.; Shokralla, S.; Curry, C.; Baird, D.J.; Monk, W.A.; King, I.; Hajibabaei, M. Large-Scale Biomonitoring of Remote and Threatened Ecosystems via High-Throughput Sequencing. PLoS ONE 2015, 10, e0138432. [CrossRef]

55. Carvalho, S.; Aylagas, E.; Villalobos, R.; Kattan, Y.; Berumen, M.; Pearman, J.K. Beyond the Visual: Using Metabarcoding to Characterize the Hidden Reef Cryptobiome. Proc. R. Soc. B Biol. Sci. 2019, 286, 20182697. [CrossRef]

56. Stat, M.; Huggett, M.J.; Bernasconi, R.; Dibattista, J.D.; Berry, T.E.; Newman, S.J.; Harvey, E.S.; Bunce, M. Ecosystem Biomonitoring with EDNA: Metabarcoding across the Tree of Life in a Tropical Marine Environment. Sci. Rep. 2017, 7, 12240. [CrossRef]

57. Lim, N.K.M.; Tay, Y.C.; Srivathsan, A.; Tan, J.W.T.; Kwik, J.T.B.; Baloğlu, B.; Meier, R.; Yeo, D.C.J. Next-Generation Freshwater Bioassessment: EDNA Metabarcoding with a Conserved Metazoan Primer Reveals Species-Rich and Reservoir-Specific Communities. R. Soc. Open Sci. 2016, 3, 160635. [CrossRef]

58. Chariton, A.A.; Court, L.N.; Hartley, D.M.; Colloff, M.J.; Hardy, C.M. Ecological Assessment of Estuarine Sediments by Pyrosequencing Eukaryotic Ribosomal DNA. Front. Ecol. Environ. 2010, 8, 233-238. [CrossRef]

59. Carew, M.E.; Kellar, C.R.; Pettigrove, V.J.; Hoffmann, A.A. Can High-Throughput Sequencing Detect Macroinvertebrate Diversity for Routine Monitoring of an Urban River? Ecol. Indic. 2018, 85, 440-450. [CrossRef]

60. Gardham, S.; Hose, G.C.; Stephenson, S.; Chariton, A.A. DNA Metabarcoding Meets Experimental Ecotoxicology: Advancing Knowledge on the Ecological Effects of Copper in Freshwater Ecosystems. Adv. Ecol. Res. 2014, 51, 79-104. [CrossRef]

61. Xie, Y.; Wang, J.; Yang, J.; Giesy, J.P.; Yu, H.; Zhang, X. Environmental DNA Metabarcoding Reveals Primary Chemical Contaminants in Freshwater Sediments from Different Land-Use Types. Chemosphere 2017, 172, 201-209. [CrossRef]

62. Xie, Y.; Hong, S.; Kim, S.; Zhang, X.; Yang, J.; Giesy, J.P.; Wang, T.; Lu, Y.; Yu, H.; Khim, J.S. Ecogenomic Responses of Benthic Communities under Multiple Stressors along the Marine and Adjacent Riverine Areas of Northern Bohai Sea, China. Chemosphere 2017, 172, 166-174. [CrossRef]

63. Zizka, V.M.A.; Geiger, M.F.; Leese, F. DNA Metabarcoding of Stream Invertebrates Reveals Spatio-Temporal Variation but Consistent Status Class Assessments in a Natural and Urban River. Ecol. Indic. 2020, 115, 106383. [CrossRef] 
64. Bagley, M.; Pilgrim, E.; Knapp, M.; Yoder, C.; Santo Domingo, J.; Banerji, A. High-Throughput Environmental DNA Analysis Informs a Biological Assessment of an Urban Stream. Ecol. Indic. 2019, 104, 378-389. [CrossRef] [PubMed]

65. Li, F.; Altermatt, F.; Yang, J.; An, S.; Li, A.; Zhang, X. Human Activities' Fingerprint on Multitrophic Biodiversity and Ecosystem Functions across a Major River Catchment in China. Glob. Chang. Biol. 2020, 26, 6867-6879. [CrossRef] [PubMed]

66. Serrana, J.M.; Yaegashi, S.; Kondoh, S.; Li, B.; Robinson, C.T.; Watanabe, K. Ecological Influence of Sediment Bypass Tunnels on Macroinvertebrates in Dam-Fragmented Rivers by DNA Metabarcoding. Sci. Rep. 2018, 8, 10185. [CrossRef] [PubMed]

67. Andújar, C.; Arribas, P.; Gray, C.; Bruce, C.; Woodward, G.; Yu, D.W.; Vogler, A.P. Metabarcoding of Freshwater Invertebrates to Detect the Effects of a Pesticide Spill. Mol. Ecol. 2018, 27, 146-166. [CrossRef]

68. Xie, Y.; Zhang, X.; Yang, J.; Kim, S.; Hong, S.; Giesy, J.P.; Yim, U.H.; Shim, W.J.; Yu, H.; Khim, J.S. EDNA-Based Bioassessment of Coastal Sediments Impacted by an Oil Spill. Environ. Pollut. 2018, 238, 739-748. [CrossRef]

69. Laroche, O.; Wood, S.A.; Tremblay, L.A.; Ellis, J.I.; Lear, G.; Pochon, X. A Cross-Taxa Study Using Environmental DNA/RNA Metabarcoding to Measure Biological Impacts of Offshore Oil and Gas Drilling and Production Operations. Mar. Pollut. Bull. 2018, 127, 97-107. [CrossRef]

70. Cordier, T.; Frontalini, F.; Cermakova, K.; Apothéloz-Perret-Gentil, L.; Treglia, M.; Scantamburlo, E.; Bonamin, V.; Pawlowski, J. Multi-Marker EDNA Metabarcoding Survey to Assess the Environmental Impact of Three Offshore Gas Platforms in the North Adriatic Sea (Italy). Mar. Environ. Res. 2019, 146, 24-34. [CrossRef]

71. Wangensteen, O.S.; Cebrian, E.; Palacín, C.; Turon, X. Under the Canopy: Community-Wide Effects of Invasive Algae in Marine Protected Areas Revealed by Metabarcoding. Mar. Pollut. Bull. 2018, 127, 54-66. [CrossRef]

72. Harper, L.R.; Lawson Handley, L.; Sayer, C.D.; Read, D.S.; Benucci, M.; Blackman, R.C.; Hill, M.J.; Hänfling, B. Assessing the Impact of the Threatened Crucian Carp (Carassius Carassius) on Pond Invertebrate Diversity: A Comparison of Conventional and Molecular Tools. Mol. Ecol. 2020, mec.15670. [CrossRef]

73. Carew, M.E.; Metzeling, L.; St Clair, R.; Hoffmann, A.A. Detecting Invertebrate Species in Archived Collections Using NextGeneration Sequencing. Mol. Ecol. Resour. 2017, 17, 915-930. [CrossRef]

74. Elbrecht, V.; Vamos, E.E.; Steinke, D.; Leese, F. Estimating Intraspecific Genetic Diversity from Community DNA Metabarcoding Data. PeerJ 2018, 6, e4644. [CrossRef] [PubMed]

75. Lacoursière-Roussel, A.; Howland, K.; Normandeau, E.; Grey, E.K.; Archambault, P.; Deiner, K.; Lodge, D.M.; Hernandez, C.; Leduc, N.; Bernatchez, L. EDNA Metabarcoding as a New Surveillance Approach for Coastal Arctic Biodiversity. Ecol. Evol. 2018, 8, 7763-7777. [CrossRef] [PubMed]

76. Borrell, Y.J.; Miralles, L.; Huu, H.D.; Mohammed-Geba, K.; Garcia-Vazquez, E. DNA in a Bottle-Rapid Metabarcoding Survey for Early Alerts of Invasive Species in Ports. PLoS ONE 2017, 12, e0183347. [CrossRef] [PubMed]

77. Huhn, M.; Madduppa, H.H.; Khair, M.; Sabrian, A.; Irawati, Y.; Anggraini, N.P.; Wilkinson, S.P.; Simpson, T.; Iwasaki, K.; Setiamarga, D.H.E.; et al. Keeping up with Introduced Marine Species at a Remote Biodiversity Hotspot: Awareness, Training and Collaboration across Different Sectors Is Key. Biol. Invasions 2020, 22, 749-771. [CrossRef]

78. Lejzerowicz, F.; Esling, P.; Pillet, L.; Wilding, T.A.; Black, K.D.; Pawlowski, J. High-Throughput Sequencing and Morphology Perform Equally Well for Benthic Monitoring of Marine Ecosystems. Sci. Rep. 2015, 5, 13932. [CrossRef]

79. Keeley, N.; Wood, S.A.; Pochon, X. Development and Preliminary Validation of a Multi-Trophic Metabarcoding Biotic Index for Monitoring Benthic Organic Enrichment. Ecol. Indic. 2018, 85, 1044-1057. [CrossRef]

80. Cahill, A.E.; Pearman, J.K.; Borja, A.; Carugati, L.; Carvalho, S.; Danovaro, R.; Dashfield, S.; David, R.; Féral, J.-P.; Olenin, S.; et al. A Comparative Analysis of Metabarcoding and Morphology-Based Identification of Benthic Communities across Different Regional Seas. Ecol. Evol. 2018, 8, 8908-8920. [CrossRef]

81. Pearman, J.K.; Chust, G.; Aylagas, E.; Villarino, E.; Watson, J.R.; Chenuil, A.; Borja, A.; Cahill, A.E.; Carugati, L.; Danovaro, R.; et al. Pan-Regional Marine Benthic Cryptobiome Biodiversity Patterns Revealed by Metabarcoding Autonomous Reef Monitoring Structures. Mol. Ecol. 2020, 29, 4882-4897. [CrossRef]

82. López-Escardó, D.; Paps, J.; de Vargas, C.; Massana, R.; Ruiz-Trillo, I.; del Campo, J. Metabarcoding Analysis on European Coastal Samples Reveals New Molecular Metazoan Diversity. Sci. Rep. 2018, 8, 9106. [CrossRef]

83. Cowart, D.A.; Murphy, K.R.; Cheng, C.-H.C. Metagenomic Sequencing of Environmental DNA Reveals Marine Faunal Assemblages from the West Antarctic Peninsula. Mar. Genom. 2018, 37, 148-160. [CrossRef]

84. Wangensteen, O.S.; Palacín, C.; Guardiola, M.; Turon, X. DNA Metabarcoding of Littoral Hard-Bottom Communities: High Diversity and Database Gaps Revealed by Two Molecular Markers. PeerJ 2018, 6, e4705. [CrossRef]

85. Dowle, E.J.; Pochon, X.; Banks, J.C.; Shearer, K.; Wood, S.A. Targeted Gene Enrichment and High-Throughput Sequencing for Environmental Biomonitoring: A Case Study Using Freshwater Macroinvertebrates. Mol. Ecol. Resour. 2016, 16, 1240-1254. [CrossRef] [PubMed]

86. Serrana, J.M.; Miyake, Y.; Gamboa, M.; Watanabe, K. Comparison of DNA Metabarcoding and Morphological Identification for Stream Macroinvertebrate Biodiversity Assessment and Monitoring. Ecol. Indic. 2019, 101, 963-972. [CrossRef]

87. Brandt, M.I.; Trouche, B.; Henry, N.; Liautard-Haag, C.; Maignien, L.; de Vargas, C.; Wincker, P.; Poulain, J.; Zeppilli, D.; Arnaud-Haond, S. An Assessment of Environmental Metabarcoding Protocols Aiming at Favoring Contemporary Biodiversity in Inventories of Deep-Sea Communities. Front. Mar. Sci. 2020, 7. [CrossRef]

88. Kuntke, F.; de Jonge, N.; Hesselsøe, M.; Lund Nielsen, J. Stream Water Quality Assessment by Metabarcoding of Invertebrates. Ecol. Indic. 2020, 111, 105982. [CrossRef] 
89. Sun, Z.; Majaneva, M.; Sokolova, E.; Rauch, S.; Meland, S.; Ekrem, T. DNA Metabarcoding Adds Valuable Information for Management of Biodiversity in Roadside Stormwater Ponds. Ecol. Evol. 2019, 9, 9712-9722. [CrossRef] [PubMed]

90. Hajibabaei, M.; Porter, T.M.; Robinson, C.V.; Baird, D.J.; Shokralla, S.; Wright, M.T.G. Watered-down Biodiversity? A Comparison of Metabarcoding Results from DNA Extracted from Matched Water and Bulk Tissue Biomonitoring Samples. PLoS ONE 2019, 14, e0225409. [CrossRef]

91. Bush, A.; Monk, W.A.; Compson, Z.G.; Peters, D.L.; Porter, T.M.; Shokralla, S.; Wright, M.T.G.; Hajibabaei, M.; Baird, D.J. DNA Metabarcoding Reveals Metacommunity Dynamics in a Threatened Boreal Wetland Wilderness. Proc. Natl. Acad. Sci. USA 2020, 117, 8539-8545. [CrossRef]

92. Wang, X.; Wang, Q.; Yang, Y.; Yu, W. Comparison of Invertebrate Diversity in Lake Waters and Their Resting Eggs in Sediments, as Revealed by High-Throughput Sequencing (HTS). Knowl. Manag. Aquat. Ecosyst. 2020, 19. [CrossRef]

93. Leray, M.; Knowlton, N. DNA Barcoding and Metabarcoding of Standardized Samples Reveal Patterns of Marine Benthic Diversity. Proc. Natl. Acad. Sci. USA 2015, 112, 2076-2081. [CrossRef]

94. Klunder, L.; Duineveld, G.C.A.; Lavaleye, M.S.S.; van der Veer, H.W.; Palsbøll, P.J.; van Bleijswijk, J.D.L. Diversity of Wadden Sea Macrofauna and Meiofauna Communities Highest in DNA from Extractions Preceded by Cell Lysis. J. Sea Res. 2019, $152,101764$. [CrossRef]

95. Polinski, J.M.; Bucci, J.P.; Gasser, M.; Bodnar, A.G. Metabarcoding Assessment of Prokaryotic and Eukaryotic Taxa in Sediments from Stellwagen Bank National Marine Sanctuary. Sci. Rep. 2019, 9, 14820. [CrossRef] [PubMed]

96. Antich, A.; Palacín, C.; Cebrian, E.; Golo, R.; Wangensteen, O.S.; Turon, X. Marine Biomonitoring with EDNA: Can Metabarcoding of Water Samples Cut It as a Tool for Surveying Benthic Communities? Mol. Ecol. 2020, mec.15641. [CrossRef]

97. Guardiola, M.; Uriz, M.J.; Taberlet, P.; Coissac, E.; Wangensteen, O.S.; Turon, X. Deep-Sea, Deep-Sequencing: Metabarcoding Extracellular DNA from Sediments of Marine Canyons. PLoS ONE 2015, 10, e0139633. [CrossRef]

98. Leray, M.; Knowlton, N. Random Sampling Causes the Low Reproducibility of Rare Eukaryotic OTUs in Illumina COI Metabarcoding. Peer 2017, 5, e3006. [CrossRef]

99. Zizka, V.M.A.; Leese, F.; Peinert, B.; Geiger, M.F. DNA Metabarcoding from Sample Fixative as a Quick and Voucher-Preserving Biodiversity Assessment Method 1. Genome 2019, 62, 122-136. [CrossRef]

100. Carew, M.E.; Pettigrove, V.J.; Metzeling, L.; Hoffmann, A.A. Environmental Monitoring Using next Generation Sequencing: Rapid Identification of Macroinvertebrate Bioindicator Species. Front. Zool. 2013, 10, 45. [CrossRef]

101. Carew, M.E.; Coleman, R.A.; Hoffmann, A.A. Can Non-Destructive DNA Extraction of Bulk Invertebrate Samples Be Used for Metabarcoding? PeerJ 2018, 6, e4980. [CrossRef]

102. Macher, J.-N.; Vivancos, A.; Piggott, J.J.; Centeno, F.C.; Matthaei, C.D.; Leese, F. Comparison of Environmental DNA and Bulk-Sample Metabarcoding Using Highly Degenerate Cytochrome c Oxidase I Primers. Mol. Ecol. Resour. 2018, 18, 1456-1468. [CrossRef]

103. Carraro, L.; Mächler, E.; Wüthrich, R.; Altermatt, F. Environmental DNA Allows Upscaling Spatial Patterns of Biodiversity in Freshwater Ecosystems. Nat. Commun. 2020, 11, 3585. [CrossRef]

104. Martins, F.M.S.; Galhardo, M.; Filipe, A.F.; Teixeira, A.; Pinheiro, P.; Paupério, J.; Alves, P.C.; Beja, P. Have the Cake and Eat It: Optimizing Nondestructive DNA Metabarcoding of Macroinvertebrate Samples for Freshwater Biomonitoring. Mol. Ecol. Resour. 2019, 19, 863-876. [CrossRef] [PubMed]

105. Laroche, O.; Wood, S.A.; Tremblay, L.A.; Lear, G.; Ellis, J.I.; Pochon, X. Metabarcoding Monitoring Analysis: The Pros and Cons of Using Co-Extracted Environmental DNA and RNA Data to Assess Offshore Oil Production Impacts on Benthic Communities. PeerJ 2017, 5, e3347. [CrossRef] [PubMed]

106. Emilson, C.E.; Thompson, D.G.; Venier, L.A.; Porter, T.M.; Swystun, T.; Chartrand, D.; Capell, S.; Hajibabaei, M. DNA Metabarcoding and Morphological Macroinvertebrate Metrics Reveal the Same Changes in Boreal Watersheds across an Environmental Gradient. Sci. Rep. 2017, 7, 12777. [CrossRef] [PubMed]

107. Nichols, S.J.; Kefford, B.J.; Campbell, C.D.; Bylemans, J.; Chandler, E.; Bray, J.P.; Shackleton, M.; Robinson, K.L.; Carew, M.E.; Furlan, E.M. Towards Routine DNA Metabarcoding of Macroinvertebrates Using Bulk Samples for Freshwater Bioassessment: Effects of Debris and Storage Conditions on the Recovery of Target Taxa. Freshw. Biol. 2020, 65, 607-620. [CrossRef]

108. McInerney, P.J.; Rees, G.N. More (or Less?) Bounce for the Ounce: A Comparison of Environmental DNA and Classical Approaches for Bioassessment. Mar. Freshw. Res. 2018, 69, 992-996. [CrossRef]

109. Erdozain, M.; Thompson, D.G.; Porter, T.M.; Kidd, K.A.; Kreutzweiser, D.P.; Sibley, P.K.; Swystun, T.; Chartrand, D.; Hajibabaei, M. Metabarcoding of Storage Ethanol vs. Conventional Morphometric Identification in Relation to the Use of Stream Macroinvertebrates as Ecological Indicators in Forest Management. Ecol. Indic. 2019, 101, 173-184. [CrossRef]

110. Aylagas, E.; Borja, Á.; Irigoien, X.; Rodríguez-Ezpeleta, N. Benchmarking DNA Metabarcoding for Biodiversity-Based Monitoring and Assessment. Front. Mar. Sci. 2016, 3, 96. [CrossRef]

111. Pearman, J.K.; Anlauf, H.; Irigoien, X.; Carvalho, S. Please Mind the Gap-Visual Census and Cryptic Biodiversity Assessment at Central Red Sea Coral Reefs. Mar. Environ. Res. 2016, 118, 20-30. [CrossRef]

112. Elbrecht, V.; Peinert, B.; Leese, F. Sorting Things out: Assessing Effects of Unequal Specimen Biomass on DNA Metabarcoding. Ecol. Evol. 2017, 7, 6918-6926. [CrossRef]

113. Beentjes, K.K.; Speksnijder, A.G.C.L.; Schilthuizen, M.; Hoogeveen, M.; Pastoor, R.; van der Hoorn, B.B. Increased Performance of DNA Metabarcoding of Macroinvertebrates by Taxonomic Sorting. PLoS ONE 2019, 14, e0226527. [CrossRef] 
114. Al-Rshaidat, M.M.D.; Snider, A.; Rosebraugh, S.; Devine, A.M.; Devine, T.D.; Plaisance, L.; Knowlton, N.; Leray, M. Deep COI Sequencing of Standardized Benthic Samples Unveils Overlooked Diversity of Jordanian Coral Reefs in the Northern Red Sea. Genome 2016, 59, 724-737. [CrossRef] [PubMed]

115. Shum, P.; Barney, B.T.; O'Leary, J.K.; Palumbi, S.R. Cobble Community DNA as a Tool to Monitor Patterns of Biodiversity within Kelp Forest Ecosystems. Mol. Ecol. Resour. 2019, 19, 1470-1485. [CrossRef] [PubMed]

116. Turon, X.; Palac, C.; Pr, K.; Wangensteen, O.S. From Metabarcoding to Metaphylogeography: Separating the Wheat from the Chaff. Ecol. Appl. 2020, 30, 19. [CrossRef] [PubMed]

117. Obst, M.; Exter, K.; Allcock, A.L.; Arvanitidis, C.; Axberg, A.; Bustamante, M.; Cancio, I.; Carreira-Flores, D.; Chatzinikolaou, E.; Chatzigeorgiou, G.; et al. A Marine Biodiversity Observation Network for Genetic Monitoring of Hard-Bottom Communities (ARMS-MBON). Front. Mar. Sci. 2020, 7. [CrossRef]

118. Carreira-Flores, D.; Neto, R.; Ferreira, H.; Cabecinha, E.; Díaz-Agras, G.; Gomes, P.T. Artificial Substrates as Sampling Devices for Marine Epibenthic Fauna: A Quest for Standardization. Reg. Stud. Mar. Sci. 2020, 37, 101331. [CrossRef]

119. Gleason, J.E.; Elbrecht, V.; Braukmann, T.W.A.; Hanner, R.H.; Cottenie, K. Assessment of Stream Macroinvertebrate Communities with EDNA Is Not Congruent with Tissue-Based Metabarcoding. Mol. Ecol. 2020. [CrossRef]

120. Zhang, Y.; Pavlovska, M.; Stoica, E.; Prekrasna, I.; Yang, J.; Slobodnik, J.; Zhang, X.; Dykyi, E. Holistic Pelagic Biodiversity Monitoring of the Black Sea via EDNA Metabarcoding Approach: From Bacteria to Marine Mammals. Environ. Int. 2020, 135, 105307. [CrossRef]

121. Jeunen, G.-J.; Lamare, M.D.; Knapp, M.; Spencer, H.G.; Taylor, H.R.; Stat, M.; Bunce, M.; Gemmell, N.J. Water Stratification in the Marine Biome Restricts Vertical Environmental DNA (EDNA) Signal Dispersal. Environ. DNA 2020, 2, 99-111. [CrossRef]

122. Fernández, S.; Rodríguez, S.; Martínez, J.L.; Borrell, Y.J.; Ardura, A.; García-Vázquez, E. Evaluating Freshwater Macroinvertebrates from EDNA Metabarcoding: A River Nalón Case Study. PLoS ONE 2018, 13, e0201741. [CrossRef]

123. Taberlet, P.; Bonin, A.; Zinger, L.; Coissac, E. Environmental DNA: For Biodiversity Research and Monitoring; Oxford University Press: Oxford, UK, 2018; ISBN 978-0-19-182138-7.

124. Elbrecht, V.; Taberlet, P.; Dejean, T.; Valentini, A.; Usseglio-Polatera, P.; Beisel, J.-N.; Coissac, E.; Boyer, F.; Leese, F. Testing the Potential of a Ribosomal 16S Marker for DNA Metabarcoding of Insects. PeerJ 2016, 4, e1966. [CrossRef]

125. Bista, I.; Carvalho, G.R.; Tang, M.; Walsh, K.; Zhou, X.; Hajibabaei, M.; Shokralla, S.; Seymour, M.; Bradley, D.; Liu, S.; et al. Performance of Amplicon and Shotgun Sequencing for Accurate Biomass Estimation in Invertebrate Community Samples. Mol. Ecol. Resour. 2018, 18, 1020-1034. [CrossRef] [PubMed]

126. Lanzén, A.; Lekang, K.; Jonassen, I.; Thompson, E.M.; Troedsson, C. DNA Extraction Replicates Improve Diversity and Compositional Dissimilarity in Metabarcoding of Eukaryotes in Marine Sediments. PLoS ONE 2017, 12, e0179443. [CrossRef] [PubMed]

127. Sawaya, N.A.; Djurhuus, A.; Closek, C.J.; Hepner, M.; Olesin, E.; Visser, L.; Kelble, C.; Hubbard, K.; Breitbart, M. Assessing Eukaryotic Biodiversity in the Florida Keys National Marine Sanctuary through Environmental DNA Metabarcoding. Ecol. Evol. 2019, 9, 1029-1040. [CrossRef] [PubMed]

128. Deiner, K.; Lopez, J.; Bourne, S.; Holman, L.; Seymour, M.; Grey, E.K.; Lacoursière, A.; Li, Y.; Renshaw, M.A.; Pfrender, M.E.; et al. Optimising the Detection of Marine Taxonomic Richness Using Environmental DNA Metabarcoding: The Effects of Filter Material, Pore Size and Extraction Method. Metabarcoding Metagenom. 2018, 2, e28963. [CrossRef]

129. Curry, C.J.; Gibson, J.F.; Shokralla, S.; Hajibabaei, M.; Baird, D.J. Identifying North American Freshwater Invertebrates Using DNA Barcodes: Are Existing COI Sequence Libraries Fit for Purpose? Freshw. Sci. 2018, 37, 178-189. [CrossRef]

130. Shokralla, S.; Porter, T.M.; Gibson, J.F.; Dobosz, R.; Janzen, D.H.; Hallwachs, W.; Golding, G.B.; Hajibabaei, M. Massively Parallel Multiplex DNA Sequencing for Specimen Identification Using an Illumina MiSeq Platform. Sci. Rep. 2015, 5, 9687. [CrossRef] [PubMed]

131. Hollatz, C.; Leite, B.R.; Lobo, J.; Froufe, H.; Egas, C.; Costa, F.O. Priming of a DNA Metabarcoding Approach for Species Identification and Inventory in Marine Macrobenthic Communities. Genome 2017, 60, 260-271. [CrossRef] [PubMed]

132. Leray, M.; Yang, J.Y.; Meyer, C.P.; Mills, S.C.; Agudelo, N.; Ranwez, V.; Boehm, J.T.; Machida, R.J. A New Versatile Primer Set Targeting a Short Fragment of the Mitochondrial COI Region for Metabarcoding Metazoan Diversity: Application for Characterizing Coral Reef Fish Gut Contents. Front. Zool. 2013, 10, 34. [CrossRef] [PubMed]

133. Lobo, J.; Costa, P.M.; Teixeira, M.A.; Ferreira, M.S.; Costa, M.H.; Costa, F.O. Enhanced Primers for Amplification of DNA Barcodes from a Broad Range of Marine Metazoans. BMC Ecol. 2013, 13, 34. [CrossRef] [PubMed]

134. Haenel, Q.; Holovachov, O.; Jondelius, U.; Sundberg, P.; Bourlat, S.J. NGS-Based Biodiversity and Community Structure Analysis of Meiofaunal Eukaryotes in Shell Sand from Hållö Island, Smögen, and Soft Mud from Gullmarn Fjord, Sweden. Biodivers. Data J. 2017. [CrossRef]

135. Chang, J.J.M.; Ip, Y.C.A.; Bauman, A.G.; Huang, D. MinION-in-ARMS: Nanopore Sequencing to Expedite Barcoding of SpecimenRich Macrofaunal Samples From Autonomous Reef Monitoring Structures. Front. Mar. Sci. 2020, 7, 448. [CrossRef]

136. Jungbluth, M.J.; Burns, J.; Grimaldo, L.; Slaughter, A.; Katla, A.; Kimmerer, W. Feeding Habits and Novel Prey of Larval Fishes in the Northern San Francisco Estuary. bioRxiv 2020. [CrossRef]

137. Elbrecht, V.; Leese, F. Validation and Development of COI Metabarcoding Primers for Freshwater Macroinvertebrate Bioassessment. Front. Environ. Sci. 2017, 5, 11. [CrossRef] 
138. Ficetola, G.F.; Boyer, F.; Valentini, A.; Bonin, A.; Meyer, A.; Dejean, T.; Gaboriaud, C.; Usseglio-Polatera, P.; Taberlet, P. Comparison of Markers for the Monitoring of Freshwater Benthic Biodiversity through DNA Metabarcoding. Mol. Ecol. 2020, mec.15632. [CrossRef]

139. Kelly, R.P.; Closek, C.J.; O’Donnell, J.L.; Kralj, J.E.; Shelton, A.O.; Samhouri, J.F. Genetic and Manual Survey Methods Yield Different and Complementary Views of an Ecosystem. Front. Mar. Sci. 2017, 3, 283. [CrossRef]

140. Carr, C.M. Polychaete Diversity and Distribution Patterns in Canadian Marine Waters. Mar. Biodivers. 2012, 42, 93-107. [CrossRef]

141. Hajibabaei, M.; Porter, T.M.; Wright, M.; Rudar, J. COI Metabarcoding Primer Choice Affects Richness and Recovery of Indicator Taxa in Freshwater Systems. PLoS ONE 2019, 14, e0220953. [CrossRef]

142. Westfall, K.M.; Therriault, T.W.; Abbott, C.L. A New Approach to Molecular Biosurveillance of Invasive Species Using DNA Metabarcoding. Glob. Chang. Biol. 2020, 26, 1012-1022. [CrossRef]

143. Zinger, L.; Bonin, A.; Alsos, I.G.; Bálint, M.; Bik, H.; Boyer, F.; Chariton, A.A.; Creer, S.; Coissac, E.; Deagle, B.E.; et al. DNA Metabarcoding-Need for Robust Experimental Designs to Draw Sound Ecological Conclusions. Mol. Ecol. 2019, 28, 1857-1862. [CrossRef]

144. Vivien, R.; Lejzerowicz, F.; Pawlowski, J. Next-Generation Sequencing of Aquatic Oligochaetes: Comparison of Experimental Communities. PLoS ONE 2016, 11, e0148644. [CrossRef]

145. Zaiko, A.; Martinez, J.L.; Ardura, A.; Clusa, L.; Borrell, Y.J.; Samuiloviene, A.; Roca, A.; Garcia-Vazquez, E. Detecting Nuisance Species Using NGST: Methodology Shortcomings and Possible Application in Ballast Water Monitoring. Mar. Environ. Res. 2015, 112, 64-72. [CrossRef]

146. Braukmann, T.W.A.; Ivanova, N.V.; Prosser, S.W.J.; Elbrecht, V.; Steinke, D.; Ratnasingham, S.; de Waard, J.R.; Sones, J.E.; Zakharov, E.V.; Hebert, P.D.N. Metabarcoding a Diverse Arthropod Mock Community. Mol. Ecol. Resour. 2019, 19, 711-727. [CrossRef]

147. Singer, G.A.C.; Fahner, N.A.; Barnes, J.G.; McCarthy, A.; Hajibabaei, M. Comprehensive Biodiversity Analysis via Ultra-Deep Patterned Flow Cell Technology: A Case Study of EDNA Metabarcoding Seawater. Sci. Rep. 2019, 9, 5991. [CrossRef]

148. Chang, J.J.M.; Ip, Y.C.A.; Ng, C.S.L.; Huang, D. Takeaways from Mobile DNA Barcoding with BentoLab and MinION. Genes 2020, 11, 1121. [CrossRef]

149. Aylagas, E.; Borja, Á.; Rodríguez-Ezpeleta, N. Environmental Status Assessment Using DNA Metabarcoding: Towards a Genetics Based Marine Biotic Index (GAMBI). PLoS ONE 2014, 9, e90529. [CrossRef]

150. Fontes, J.T.; Vieira, P.E.; Ekrem, T.; Soares, P.; Costa, F.O. BAGS: An Automated Barcode, Audit \& Grade System for DNA Barcode Reference Libraries. Mol. Ecol. Resour. 2020. [CrossRef]

151. Buss, D.F.; Carlisle, D.M.; Chon, T.-S.; Culp, J.; Harding, J.S.; Keizer-Vlek, H.E.; Robinson, W.A.; Strachan, S.; Thirion, C.; Hughes, R.M. Stream Biomonitoring Using Macroinvertebrates around the Globe: A Comparison of Large-Scale Programs. Environ. Monit. Assess. 2015, 187, 4132. [CrossRef]

152. Mosher, B.A.; Bernard, R.F.; Lorch, J.M.; Miller, D.A.; Richgels, K.L.; White, C.L.; Grant, E.H.C. Successful Molecular Detection Studies Require Clear Communication among Diverse Research Partners. Front. Ecol. Environ. 2020, 18, 43-51. [CrossRef]

153. Sepulveda, A.J.; Nelson, N.M.; Jerde, C.L.; Luikart, G. Are Environmental DNA Methods Ready for Aquatic Invasive Species Management? Trends Ecol. Evol. 2020, 35, 668-678. [CrossRef] 